NBER WORKING PAPER SERIES

\title{
ACTING WHITE OR ACTING BLACK: MIXED-RACE ADOLESCENTS' IDENTITY AND BEHAVIOR
}

\author{
Christopher Ruebeck \\ Susan Averett \\ Howard Bodenhorn \\ Working Paper 13793 \\ http://www.nber.org/papers/w13793 \\ NATIONAL BUREAU OF ECONOMIC RESEARCH \\ 1050 Massachusetts Avenue \\ Cambridge, MA 02138 \\ February 2008
}

The authors thank David Stifel for comments and KoKo Maung and Mevan Jayasinghe for helpful research assistance. This research uses data from Add Health, a program project designed by J. Richard Udry, Peter S. Bearman, and Kathleen Mullan Harris, and funded by a grant P01-HD31921 from the National Institute of Child Health and Human Development, with cooperative funding from 17 other agencies. Special acknowledgment is due Ronald R. Rindfuss and Barbara Entwisle for assistance in the original design. Persons interested in obtaining data files from Add Health should contact Add Health, Carolina Population Center, 123 W. Franklin Street, Chapel Hill, NC 27516-2524 (addhealth@unc.edu). The views expressed herein are those of the author(s) and do not necessarily reflect the views of the National Bureau of Economic Research.

NBER working papers are circulated for discussion and comment purposes. They have not been peerreviewed or been subject to the review by the NBER Board of Directors that accompanies official NBER publications.

(C) 2008 by Christopher Ruebeck, Susan Averett, and Howard Bodenhorn. All rights reserved. Short sections of text, not to exceed two paragraphs, may be quoted without explicit permission provided that full credit, including $(\mathcal{O}$ notice, is given to the source. 
Acting White or Acting Black: Mixed-Race Adolescents' Identity and Behavior

Christopher Ruebeck, Susan Averett, and Howard Bodenhorn

NBER Working Paper No. 13793

February 2008

JEL No. J11,J13,J15,Z13

\begin{abstract}
$\underline{\text { ABSTRACT }}$
Although rates of interracial marriage are on the rise, we still know relatively little about the experiences of mixed-race adolescents. In this paper, we examine the identity and behavior of mixed-race (black and white) youth. We find that mixed-race youth adopt both types of behaviors -- those that can be empirically characterized as "black" and those that can be characterized as "white". When we combine both types of behavior, average mixed-race behavior is a combination that is neither white nor black, and the variance in mixed-race behavior is generally greater than the variance in behavior of monoracial adolescents, especially as compared to the black racial group. Adolescence is the time during which there is most pressure to establish an identity, and our results indicate that mixed-race youth are finding their own distinct identities, not necessarily "joining" either monoracial group, but in another sense joining both of them.
\end{abstract}

Christopher Ruebeck

Simon Center

Department of Economics

Lafayette College

Easton, PA 18042

ruebeckc@lafayette.edu

Susan Averett

Simon Center

Dept. of Economics

Lafayette College

Easton, PA 18042

AVERETTS@LAFAYETTE.EDU
Howard Bodenhorn

Department of Economics \& Business

William Simon Center

Lafayette College

Easton, PA 18042-1776

and NBER

bodenhoh@lafayette.edu 


\section{Introduction}

The constant of the postwar American family is change. Abundant scholarship documents the increasing likelihood of divorce and single parenthood, later age at first marriage, and the rise of extramarital cohabitation, same-sex unions, and interracial marriage (Stevenson and Wolfers 2007). The rise of interracial marriage since the US Supreme Court struck down state anti-miscegenation laws in 1967 is notable. Between 1970 and 2000 the number of black-white marriages increased five-fold (Rosenfeld and Kim 2005). By 2000 over seven percent of black men were married to white women, and nearly 3 percent of black women were married to white men (Fryer 2007). Although interracial marriage remains relatively rare it is on the rise.

Scholars have focused on several features of interracial marriage, including sociological and economic studies of the marriage market (Rosenfeld and Kim 2005; Joyner and Kao 2005; Fryer 2007), how the law accommodates nontraditional unions (Kennedy 2003; Romano 2003), the consequences of interracial mating for the psychological health and sociological adjustments of these unions' mixed-race offspring (Tizard and Phoenix 2002); the educational achievement of mixed-race children (Kao 1999; Harris and Thomas 2002; Herman 2002); risk taking by mixed-race youth (Udry et al 2003); as well as the personal and social construction of mixed-race identities (Harris 2001; Harris 2002; Harris and Sim 2002). Our study addresses the last three of these issues in that we investigate how a mixed-race identity influences a wide range of teenage academic and risk-taking behaviors relative to the behaviors of their monoracial peers.

The first systematic social science studies of mixed-race people in the early twentieth century argued that, because they were perpetual outsiders, mixed-race individuals were more prone to psychological disorders and social pathologies than monoracial individuals (Park 1929; Park 1931; Stonequist 1937). But recent increases in interracial marriage and the number of mixed-race children have spawned a new interest in their experiences and development. While the modern literature accepts that modern mixed-race individuals must navigate certain strains, conflicts and ambiguities not faced by monoracial individuals, there is abundant evidence that mixed-race youth develop positive self-images and healthy identities (Daniel 1996; Tizard and Phoenix 2002). 
We investigate the extent to which mixed-race youth adopt the behavioral norms of their white or black peers or whether they sometimes adopt distinct behaviors that are neither stereotypically black nor white. We find that mixed-race youth struggle to establish a unique identity in at least some dimensions. It is important not to equate identity with behavior, of course, but much behavior is purposeful and designed to project a public image or persona not inconsistent with the person's beliefs or the salience an association holds for that individual.

One of this study's contributions to the literature is our rejection of the standard economic practice of viewing race, like sex, as immutable and an exogenously determined datum. Sociology and psychology have long recognized that race, like any other personal characteristic, is socially constructed and therefore changeable. Economists have only recently begun to investigate the extent to which economic processes influence racial determination and vice versa (Darity et al 2006). Although macro-level social processes establish the choice set of identities available to the individual, there remains an element of choice in racial identification. Moreover, racial identification and the resulting behaviors translate physical characteristics into human capital with an economic value.

It is also important to emphasize that this study focuses on mixed-race youth defined by ancestry or parents' races. It addresses issues of complexion or phenotype indirectly, if at all. An emergent economic literature connects phenotype and outcomes, and generally finds that lighter complected individuals earn higher incomes, accumulate more wealth, and generally fare better in several dimensions that their darker complected peers (Bodenhorn 2003; Goldsmith et al 2006; Hersch 2006; Gyimah-Brempong and Price 2006; Bodenhorn and Ruebeck 2007; Goldsmith et al 2007). We cannot draw a connection between mixed-race individuals and complexion-based differentials because, as Rangel (2007) shows, race mixing does not uniquely map into phenotype because parents of given phenotypes produce offspring drawn from a distribution of potential complexions. The data we employ identify mixed-race individuals, but reveal nothing definitive about their complexions.

Specifically, we use a rich data set on adolescents to test hypotheses about differences in mixed-race and monoracial behaviors as evidence for differences in identity. Although complexion is not definitively measured, 
the data do allow us to use a number of different definitions and so compare our findings across the various measures of adolescents' racial group. The rest of this paper proceeds as follows. In section 2 we introduce a model of identity and behavior which provides a framework for our empirical analysis. In section 3 , we discuss our data and our different measures of race. Section 4 presents our empirical model and summary statistics. Section 5 presents the results of our classification of adolescent behavior along racial lines, while section 6 presents our results aimed at determining the variation in mixed-race individual's identities. Section 7 provides the results of a sensitivity analysis while section 8 concludes our analysis.

\section{Conceptual apparatus}

In this section, we outline a stylized model of identity and behavior inspired by Akerlof and Kranton (2000; 2002), one that follows from Benjamin et al. (2007). The model organizes our thinking about the issues of racial identity and behavioral choices among mixed-race children, but we do not provide a formal test of the theory per se. It nevertheless remains a useful heuristic and the empirical results reported below are consistent with the model's predictions. In our framework, peer and familial pressures to adopt certain identity-related behaviors influence the individual's choice of activities, based on his or her personal preferences and the salience of racial identification. Models based on Akerlof and Kranton's framework (see also Bodenhorn and Ruebeck, 2003) also recognize that economic incentives can influence the choice of identity directly. In fact, it is the tension between pecuniary and psychic incentives that motivate these and related theories.

Let $x$ be some decision variable, such as how much of a certain activity an individual may engage in. The choice of activities may or may not be associated with existing racial behavioral norms. Individuals identify with a given racial category $R$ with salience $s$. Let $x_{0}$ denote the optimal engagement in activity $x$ absent racial identity considerations. Similarly, let $x_{R}$ denote the existing racial behavioral norm associated with an activity and prescribed for members of race $R$ by the members of each race. The behaviors are stereotypical in the sense that members of each race collectively define what they believe to be appropriate behavior for others of the same race. 
We assume there are two races, $R=w$ (white) or $b$ (black), each with reasonably well established behavioral norms. There exist as well members of a third, emergent mixed-race group for whom a prescribed norm does not yet exist. Mixed-race individuals face peer and familial pressures to adopt behaviors consistent with one of the existing racial norms, while personal preferences and economic incentives may imply higher levels of utility from alternative behaviors consistent with neither existing racial norm. Assume further that mixed-race individuals place weights $0 \leq w_{b}(s), w_{w}(s) \leq 1$ on conforming to either the black or white behavioral norms, where s represents the salience or strength of a particular racial identity to the individual. The individual chooses $x$ to maximize

$$
U=-\left(1-w_{w}(s)-w_{b}(s)\right)\left(x-x_{0}\right)^{2}-w_{w}(s)\left(x-x_{w}\right)^{2}-w_{b}(s)\left(x-x_{b}\right)^{2}
$$

We further assume that $w_{b}(0)=w_{w}(0)=0$ and that $w_{b}^{\prime}(\mathrm{s}), w_{w}^{\prime}(s)>0$. The assumptions and the form of the utility function imply that deviations from a racial norm prescribed by peers or family members cause disutility that is increasing in the salience of racial identity $s$, the power of the individual's affiliation with a racial norm, and the distance between a given activity and the racial norm. The individual also suffers disutility when she deviates from her personal optimum level of activity $x$. Thus, the individual faces a tradeoff between being true to herself and being true to social expectations regarding her behavior based on the racial image she projects.

The first-order condition of (1) defines the optimal level of $x$,

$$
x^{*}=\left(1-w_{w}(s)-w_{b}(s)\right) x_{0}+w_{w}(s) x_{w}+w_{b}(s) x_{b},
$$

a weighted average of the individual optimum and the existing racial norms. This specification does not limit mixed-race individuals to adopt behaviors that are convex combinations of existing black and white behaviors, rather they are convex combination of existing black behaviors, white behaviors and behaviors consistent with the individual's personal optimum behavior absent identity pressures. The first right-hand side term affords the 
mixed-race youth the opportunity to adopt behaviors that are neither stereotypically black nor stereotypically white, behaviors that may be "outside" the established racial norms.

The model yields two predictions that bear on our study of mixed-race youth.

Prediction 1: The stronger the salience of a given racial behavioral norm, the closer the individual $x^{*}$ will be to either $x_{b}$ or $x_{w}$.

An example, although not one that we test directly here, is the still-controversial "acting white" hypothesis (Fordham and Ogbu 1986; Austen-Smith and Fryer 2005; Fryer and Torelli 2005; Ferguson 2006; Tyson and Darity 2005). If a mixed-race youth faces peer pressures to express black identity through engagement in stereotypically black behaviors, and black behaviors are "oppositional" in that they reject white norms of academic achievement, peer pressure may lead him to achieve a lower grade point averages. If the "acting white" phenomenon is real and black racial salience is powerful for mixed-race youth in academic matters, we may observe lower grade point averages among mixed-race youth than would be predicted by observable family, personal and school characteristics. Although Ferguson (2006) fails to find evidence of them, sociologists and psychologists report pressures placed on mixed-race youth by monoracial youth to demonstrate racial authenticity in various dimensions, so we may observe multi-race youth adopting a wide range of behaviors, depending on the salience of white or black race in a particular circumstance (Tizard and Phoenix 2002; Williams 1996; Root 1997).

Prediction 2: The responsiveness of the individual's engagement in activity $x$ to racial salience is determined by

$$
\delta x^{*} / \delta s=w_{w}^{\prime}(s)\left(x_{w}-x_{0}\right)+w_{b}^{\prime}(\mathrm{s})\left(w_{b}-x_{0}\right) .
$$

The sign of which depends, of course, on the signs of $\left(x_{w}-x_{0}\right)$ and $\left(w_{b}-x_{0}\right)$ and the relative magnitudes of the relevant terms, which cannot be known absent a specific parameterization of the model. Nevertheless, the 
general result reveals that the individual's adjustment to changes in salience depends on the relative distances of the mixed-race youth's personal optimum engagement in an activity and the prescribed racial behavioral norms.

Suppose, without loss of generality, that $x_{w}-x_{0}>0$ and $x_{b}-x_{0}<0$ (or, that the mixed-race youth's personal optimum is closer to the black than the white behavioral norm), then the effect of racial salience on the behavioral choice will be determined by

$$
\delta^{2} x^{*} / \delta s^{2}=w_{w}^{\prime \prime}(s)\left(x_{w}-x_{0}\right)+w_{b}^{\prime \prime}(\mathrm{s})\left(w_{b}-x_{0}\right) .
$$

By assumption $\left(x_{w}-x_{0}\right)>\left(x_{b}-x_{0}\right)$ and we then have

$$
\delta^{2} x^{*} / \delta s^{2}>0 \text { if and only if } w_{w}^{\prime \prime}(s), w_{b}^{\prime \prime}(s)>0 \text { and } w_{w}^{\prime \prime}(\mathrm{s})>w_{b}^{\prime \prime}(s) \text {. }
$$

Given the assumptions, equation (5) implies that the salience of whiteness for mixed-race youth increases more rapidly the greater the initial distance between the white norm and the youth's optimum engagement in $x$. But depending on the forms of the w(s)'s and the value of s itself, $\delta^{2} x^{*} / \delta s^{2}$ might be either positive or negative. As Benjamin et al (2007) note, it may be that individuals with greater racial salience are more accepting of racial norms $\left(\mathrm{w}^{\prime \prime}>0\right)$; or it might be that individuals become saturated with the racial norm $\left(\mathrm{w}^{\prime \prime}<0\right)$.

To summarize, mixed-race youth behaviors may reveal greater diversity than monoracial behaviors. Because they face conflicting familial and peer pressures regarding "correct" behavior, mixed-race youth will sometimes engage in stereotypically white behaviors, stereotypically black behaviors, and unique behaviors that are neither black nor white. Moreover, because the salience of race is likely to vary more across mixed-race than monoracial youth in at least some circumstances, we expect to observe a greater variance of mixed-race behaviors driven by the absence of established mixed-race behavioral norms. 


\section{Data}

To assess the connection between behaviors and identity among mixed-race individuals, we use data collected by the Adolescent Health Survey (commonly referred to as AddHealth), a school-based nationally representative survey of students, parents, and school administrators concerning the health-related behaviors of adolescents in grades 7 through 12. Research dating to at least Erikson (1968) reveals that the initial steps toward identity formation are taken in adolescence, when youth have accumulated enough experience to adequately assess life goals and personal values (see Furstenberg 2000 for a recent review). Archer (1982) argues that adolescence, especially early to mid-adolescence, represents a critical period in identity formation because the physical changes surrounding puberty and the widening of the circle of acquaintances typically result in self-appraisal and emergent concerns about behavior. Given the increasing number of mixed-race individuals going through the process of identity development, sociologists and psychologists have grown increasingly interested in their experiences (Tizard and Phoenix 2002). We consider the choices that adolescents make, choices that are not only a function of their emergent identity but determinants of their future livelihoods as well. Thus, our research contributes to this emergent literature because it is among the first to offer an empirical assessment of mixed-race behaviors and identity formation through the lens of "the economics of identity."

Adolescents were interviewed for the AddHealth study in consecutive academic years, 1994-95 (Wave 1) and 1995-96 (Wave 2). In each wave, information on a wide range of risky and pro-social behaviors, academic outcomes, and family characteristics was collected. The Wave 1 survey included two components: an in-school survey and an at-home survey. The in-school survey was given during one class period (45 to 60 minutes) to more than 90,000 students and was administered between September 1994 and April 1995. The athome survey, a sub-sample of the in-school sample, was administered to 20,745 adolescents, and was typically conducted in the adolescent's home in a one to two hour period. The Wave 1 survey was administered between September 1994 and December 1995. To reduce the likelihood of purposive misreporting on sensitive topics, interviewers assured students that their answers could not be matched to their names and questions were 
answered on a computer controlled by the adolescent student. Wave 2, which was also conducted at-home, was administered to nearly 15,000 of the same students surveyed in Wave 1 approximately one year later. At Wave 1 , the mother (or other female head of the household) of the originally-sampled adolescent was asked to participate in a 40-minute, interviewer-administered survey regarding the health status and behaviors of the adolescent, home environment, and the adolescent's interpersonal relationships. AddHealth preferred to have the mother fill out the parent's questionnaire because mothers are generally believed to be more familiar than fathers with the schooling, health status, and health behaviors of their children.

We make use of responses collected from the in-school, at-home, and parental components of the survey. Our first task is to identify mixed-race adolescents, and towards this purpose AddHealth provides multiple sources. Although the in-school survey asked each adolescent to self-report her or his race with the option to select more than one racial category, self-reported race is potentially endogenous to identity development and to the observable behaviors and other outcomes we study. We thus use as our primary source of racial identity the parental survey conducted in the Wave 1 at-home survey in which a parent (usually the mother as explained above), was asked to report their own race, as well as the race of their partner. Information on the parents' races should be less endogenous than the adolescent's self-reported race is to the adolescent's outcomes. Parents, too, could select more than one racial category. Because our interest is in the black/white dichotomy which characterizes the "acting white" research, we limit ourselves to considering those respondents who noted that they were black and/or white. Respondents who did not check either black or white are not included in our analysis. Note that if an individual marked white, black, or both but also marked one of the other three categories that AddHealth records (asian, American Indian, other), we did not drop them because we already have a small sample of mixed race adolescents. Thus, when we use the term "mixed race", we use it to refer to those individual who are reported (by themselves or their parents) to at least be both black and white. ${ }^{1}$

\footnotetext{
${ }^{1}$ We label this group "mixed-race" for convenience and expositional clarity. In so doing, we sacrifice precision, but because no generally acceptable terminology has yet emerged, we trade precision for a greater rhetorical clarity. Other studies have investigated the experiences of children from racially mixed parents and have drawn parallels between their experiences and those of black-white mixed race (Kao 1999; Harris and Sim 2002).
} 
Our use of parental-based adolescent race forces us to limit our sample to adolescents living in intact families because single parents are not asked to report the other biological parent's race. Although this poses some disadvantages, mostly because black youth are significantly less likely to live in intact families and children in single-parent homes are more likely to engage in risky behaviors than children in traditional twoparent households (McLanahan and Sandefur 1994), focusing our attention on this group reduces racial identification endogeneity and eliminates at least one confounding source of variation (Bryson 1995). Another disadvantage to using the at-home sample is that we have few adolescents whose parents report a racially mixed relationship. To address this drawback, we merge the data from both Waves 1 and 2 of AddHealth so that each mixed-race adolescent is observed twice. As is typical in longitudinal data sets, the racial identification questions were asked at baseline (Wave 1) and not at Wave 2. After linking the parental race information with the adolescent information in Waves 1 and 2 (we refer to the combination of Waves 1 and 2 as the at-home sample) and dropping those observations without a sample weight, we identified 63 adolescents who had one white parent and one black parent and from whom we draw our principal conclusions about mixed-race behavior and identity. We take care not to draw sweeping generalizations based on our modest sample size. To address the more general population and increase the sample size of all racial groups, but at the potential expense of endogenous racial identification, we then repeat our analysis with racial group identified directly by the surveyed adolescent, widening the sample to include non-intact families in Waves 1 and 2 and then the larger in-school sample. The advantage of the in-school data is that is includes responses from more than 90,000 respondents and about 800 of these self-report being mixed-race. We will report on results using the following five samples: (1) Waves $1 \& 2$ at-home survey, intact families, race based on parents; (2) Waves $1 \&$ 2 at-home survey, intact families, race based on adolescents' self-report; (3) Waves $1 \& 2$ at-home survey, all adolescents, self-reported race; (4) in-school survey, intact families, self-reported race; and (5) in-school survey, all adolescents, self-reported race. We choose these samples to logically expand beyond the first (preferred) sample and make relevant comparisons among the results. The at-home samples have, in addition to parents' race, a more rich set of behaviors; our analysis of the two in-school samples thus depends on a smaller set of behaviors and control variables. 
Using our preferred sample (intact families from Waves 1 and 2 of the at-home sample), Table 1 reveals

that there is not perfect agreement between adolescents' self-reports and parental racial categorizations. Of the 63 adolescents in Wave 1 from intact inter-racial families, 26 identified themselves as mixed-race: 3 with a black mother and white father, and 23 with a white mother and black father. The thirty-seven remaining with racially mixed parents mostly identified as "Black" (17), some as "White" (7) and the rest as "Other" (13). The category "Other" is small because we have excluded adolescents whose parents did not check either black or white. Although it captures potential errors in coding or completing the survey, most of these "Other" observations are purposive choices by adolescents of one of the other three categories provided by AddHealth.

\section{Table 1: Adolescents' and parents' self-reported racial categories_Wave 1 only, intact families}

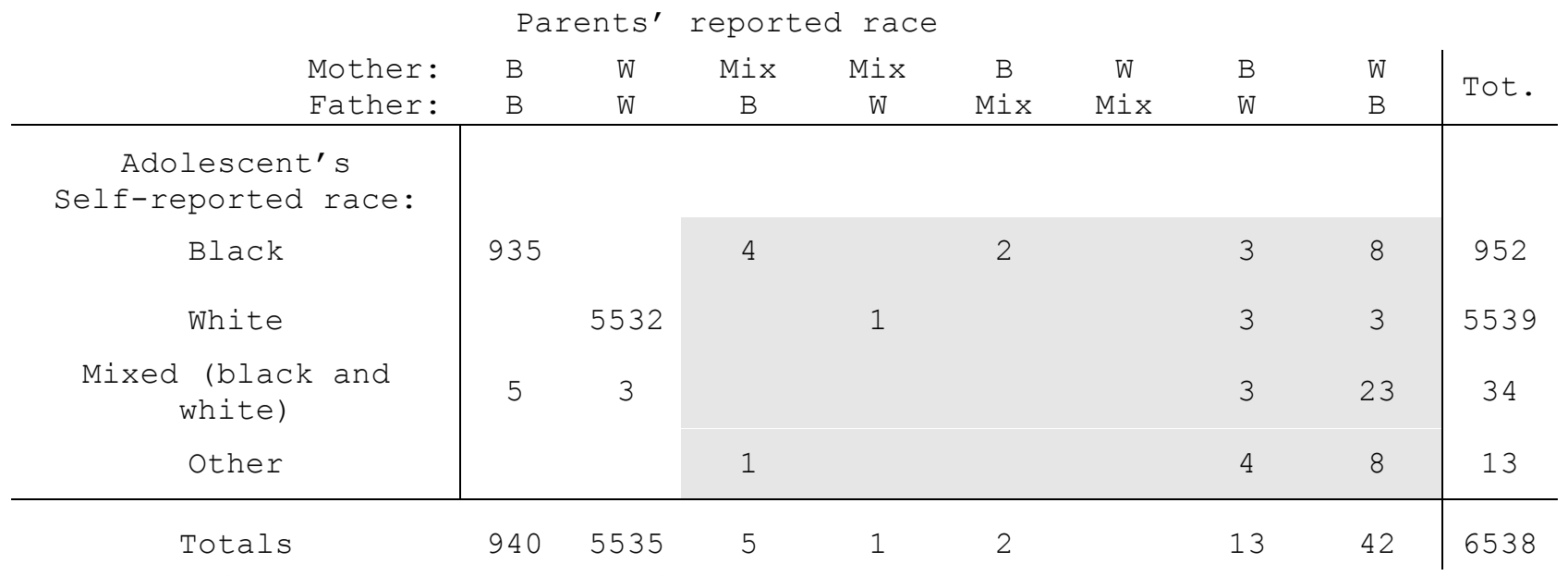

Notes to Table 1: The grey cells are the 63 adolescents identified as mixed-race by their parents' racial identification. $\mathrm{B}=$ black; $\mathrm{W}=$ white; Mix = mixed-race for parents. Parents, like their adolescent children, could self-report more than one racial identifier and several did. We consider that person's child to be mixed-race (black and white) if one parent selected black as at least one identifier and the other chose white as at least one identifier. We have a greater number of observations in later tables that use both Waves 1 and 2 ; this table only reports on Wave 1 observations.

Our focus is on the adolescents' race as implied by parental race and we find results robust to our methods of measuring adolescent race when we extend our results to include samples in which adolescent race is self-reported, but we conclude this section with a discussion of the disagreements between the measures. Using a different subset of the AddHealth data, Harris and Sim (2002) conclude that race is fluid among a significant proportion of adolescents. Their study finds that, whereas 6.8 percent of survey respondents report a mixed racial heritage when completing the in-school survey, only 3.6 percent responded similarly on the athome portion. When considering intact, two-parent families they find $4.8 \%$ of students come from mixed-race 
backgrounds. Hitlin et al. (2006) extend the work of Harris and Sim by using Waves 1 and 3 of the Addhealth survey and report that between Waves 1 and 3 there are racial identification changes. ${ }^{2}$

AddHealth interviewers were also asked to "Code the race of the respondent based on your observation alone." Unlike respondents, however, interviewers were not allowed to select more than one racial category in describing respondents, and they answered this question after respondents provided their self-identification. As it stands, interviewers coded 14 of those who self-reported black as white and 18 of those self-reporting white as black. Of those who self-reported mixed, 70 percent were classified as black by the interviewers, indicating that the classification heuristic used by the interviewers appears consistent with Davis' (1991) contention that the "one-drop rule" still holds sway in modern America. That is, any individual with any trace of black heritage is more likely to be viewed as black. When we use parental race reports (the group described in Table 1), we find that of the 63 adolescents with one black and one white parent, 31 are categorized as black by interviewers, 20 as white, and the remaining 11 as one of the other three racial categories. It appears that when the parental race reports are used to classify the adolescent the "one-drop rule" tended to break down. ${ }^{3}$

\section{4: Empirical method and summary statistics}

Our analysis of mixed-race behaviors and their relationship to identity choices unfolds in three steps. We first look for differences in average behaviors between the monoracial white and black adolescents. These differences are predominant or typical rather than stereotypical because our data-driven method sometimes produces results that differ from popular portrayals. That first step allows us to empiricially identify behaviors that are predominantly white, predominantly black, or neither. Our second step investigates differences in mean behavior between the black, white, and mixed-race groups, allowing us to categorize mixed-race behavior

\footnotetext{
${ }^{2}$ We not make use of the Wave 3 data for our analysis as the youth were no longer adolescents at the time Wave 3 was fielded.

${ }^{3}$ To offer some insight into the factors influencing adolescent racial self-reporting, we regressed a binary identifier of the adolescent's self-reported mixed-race identity against mother's race, father's race, whether the parent was born in the U.S., parents' social status, and parental education using a standard probit specification. The results (not reported here) reveal that adolescents with black mothers and white fathers are significantly less likely to self-report as mixed-race than adolescents with white mothers and black fathers, as Table 1 would lead us to expect. Those with native-born fathers are also more likely to report being mixed. When parental education is included, we find that those with college-educated mothers are more likely to report being mixed-race, as are those with mother's who receive welfare.
} 
relative to other racial groups. Our analysis then turns to inter-group differences in the intra-group variance of behaviors. Throughout these analyses, we investigate the sensitivity of the results to alternative samples of the AddHealth data and alternative measures of racial identity.

Our empirical model is

$$
Y_{i t s}=\alpha+\beta_{b} B_{i s}+\beta_{b w} M_{i s}+X_{i t s}^{\prime} \gamma+\delta_{s}+\varepsilon_{i s t},
$$

where $i$ subscripts individuals, $s$ subscripts schools, and $t$ subscripts time (Waves 1 and 2). AddHealth is a school-based sampling design, so $\delta$ controls for school-level fixed effects ${ }^{4}$ to net out time invariant heterogeneity that may be correlated with unobservables in the idiosyncratic error $\varepsilon$. $Y$ represents the behavior under study, and $X$ is a vector of demographic characteristics. Our explanatory variables of interest are the racial categories: white is the omitted category, $B=1$ if the individual is identified as black by their parents and zero otherwise, and $M=1$ if the respondent is identified as mixed (black and white) by their parents and zero otherwise. Note that race is only subscripted over $i$ and $s$ because individuals were only asked their race in Wave 1. Because $Y$ is sometimes measured as a dichotomous variable and sometimes as an index or the frequency of an event, we estimate the parameters in (6) using linear probability models. This specification (rather than probit or logit) is also necessary in order to include the school fixed effects. Because we observe some adolescents more than one, robust standard errors are reported.

Table 2 presents the variable definitions and the sample means for the more than 40 behaviors and attitudes we analyzed as dependent variables. The variables can be grouped into five broad behavioral categories: sexual activity, substance abuse, delinquent behaviors, time use and school-related behaviors. Most responses to survey questions regarding behavioral choices are recorded as dichotomous variables; for example, “Have you ever been a regular cigarette smoker?" Some, however, are recorded as frequencies; for example, "How many hours did you spend watching television last week?"

In addition (and included in Table 2), we also created three behavior indices by summing a student's responses across several survey items and then dividing by the number of items over which the index was

\footnotetext{
${ }^{4}$ Random effects specifications were rejected by the Hausman test in almost every case.
} 
created. The question groups were implied by the survey structure because they were asked in a sequential manner, as in: "How often have you had trouble at school with: homework? teachers?" etc. The first index combines attitudes towards school and includes six questions. The second index summarizes four negative school-related troubles, such as having difficulties with teachers, with fellow students, with paying attention in class, or with completing homework assignments. A third index averages over nine behaviors to create a delinquency scale similar to that created by Resnick et al. (1997). In every case, a calculation of Cronbach's alpha produced a statistic exceeding 0.7 , a commonly used cutoff for inferring that the indices are internally consistent.

Taken on their own and without controlling for any other factors, the behavioral questions and the behavior indices summarized in Table 2 present a complex portrait of mixed-race behaviors. Although mixedrace adolescents, on average, report higher satisfaction with school than whites or blacks, they simultaneously report having more troubles in school and skipping school more often. Mixed-race adolescents are also more likely than either blacks or whites to report having had sexual intercourse, to watch more television, and to exhibit higher delinquency rates. If behavioral choices are indicative of identity development, the simple averages reported in Table 2 suggest that, as a group, mixed-race adolescents are engaged in a wide range of activities. The averages conceal whether each mixed-race individual is experimenting with a wider range of behaviors or whether there is a wider variance of behaviors across individuals. The third step of our empirical analysis confronts this issue.

Racial behavioral differences documented elsewhere for adolescents are evident here. We find that, for example, white adolescents are more likely to have regularly smoked cigarettes, drank alcohol, and smoked marijuana in the 30 days prior to the survey, while blacks were more likely to report having been sexually active. These differences are consistent with data from the 2005 National Youth Risk Behavior Survey. Because our preferred sample includes only intact families, the results are not necessarily representative of adolescents in other family types. As explained in Section 3, we also expand our investigations to include wider samples from the AddHealth data. In the appendix, Tables A1 and A2 report summary statistics for the behaviors and 
attitudes of our four additional samples; Table A1 for the at-home samples and Table A2 for the in-school samples. For details, see the discussion in the appendix.

Table 3 presents the means of our control variables: the adolescent's age, sex, place of residence, and religiosity, as well as controls for parental income, age, education, nativity and occupation. Dummy variables are included to account for missing data in the relevant cells. Similar tables for the other samples are reported in the appendix Tables A3 and A4. The controls reveal some additional notable differences between mixed-race adolescents and their monoracial peers. Mixed-race youth reside in households with lower average incomes, are more likely to live in an urban environment, are more likely than black youth to be Catholic, are more likely to have foreign-born parents, to have an unemployed parent, and to live in a household receiving welfare payments.

\section{5: Race and behavioral propensities: Which behaviors are "black"? Which behaviors are "white"?}

Figure 1 provides a heuristic for interpreting the first step in our analysis. Behaviors are classified as predominantly black or white depending on the statistical significance of the coefficient on the black indicator variable estimated by Equation 6 for each behavior or attitude. The first significant contribution of our research is that this approach itself yields some interesting and potentially counterintuitive results. Those behaviors that are not associated with either monoracial group are not included in subsequent analyses.

\section{Figure 1. Classifying behavior as Black or White}

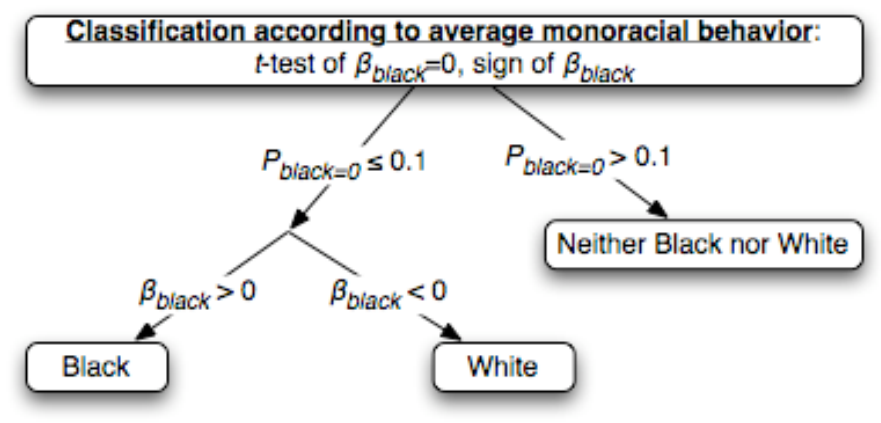

Tables $4 \mathrm{a}, 4 \mathrm{~b}$, and $4 \mathrm{c}$ present the results of classifying behaviors according to Figure 1 . To conserve space, we do not report the estimated coefficients on the control variables for our preferred sample in Table 4a. 
For the same reason, we summarize only the classifications from Figure 1 for our other four samples in Tables $4 \mathrm{~b}$ and $4 \mathrm{c}$, omitting the estimated coefficients entirely. The classification results from Table $4 \mathrm{a}$ are repeated in Table $4 \mathrm{~b}$, along with the other two samples from the at-home survey. Table $4 \mathrm{c}$ reports the classification results for our two samples from the in-school survey. Notably, with respect to black and white behaviors, there are no contradictions in categorization among the three samples in Table 4b, nor between the two samples in Table 4c. We do see that larger sample sizes (recorded in Tables 2, A1, and A2) generally lead to fewer categorizations as "Neither". Our discussion of the results focuses on the parent-identified adolescent race results presented in Table $4 \mathrm{a}$ and repeated in the first column of Table $4 \mathrm{~b}$.

Of the 45 behaviors and outcomes, ceteris paribus, only five are clearly associated with black adolescents, while 23 are associated with white adolescents, and the remaining 17 are not associated with either monoracial group. Blacks are more likely to have engaged in sexual intercourse, to spend more hours watching television, to spend more hours watching videos, and to spend more time playing video or computer games. One outcome, which is more suggestive of a host of attendant behaviors rather than any one behavior (and of particularly ambiguous causality), is that blacks are more likely to have been suspended from school during the academic year. Predominantly white adolescent attitudes include believing that students at their school are prejudiced, feeling close to other students at their school, feeling that teachers treat them fairly, and feeling generally happy at school, skipping school, having difficulty paying attention in school, and completing their homework. Whites are also more likely than blacks to engage in delinquent behaviors, including graffiti, damaging property, and theft. Finally, whites are more likely than blacks to play sports, skate and "hang out" with their friends.

\section{6: Mixed-race identities implied by average behavior}

To prepare for the second step of our analysis, we aggregate the white and black behaviors. Table 5 outlines our aggregation approach. We are most interested in three new indices: one of all white behaviors, one of all black behaviors, and one combining them all. We also take an intermediate step for each of these three aggregates because we have both dichotomous variables and frequency variables. To aggregate the 
dichotomous variables we simply add them. To aggregate the frequency variables, we first rescale each

variable and then divide by its maximum value so that it ranges from 0 to 1 . To combine the dichotomous and rescaled frequency variables we add them. Note that higher values of our white indices indicate acting more "white" while higher values of the black indices indicate acting more "black". Thus before combining the black variables and white variables, we subtract each black index from its theoretical maximum so that both the black and white variables (when combined) have the same direction of black and white identity. As a result, higher values of the combined white and black indices indicate acting more "white".

\section{Table 5. Aggregating using the results in Tables $4 b$ and $4 c$}

Variable

Definition

White Dichotomous

White Frequency

White All

Black Dichotomous

Black Frequency

Black All

Aggregate Dichotomous

Aggregate Frequency

Aggregate All
The sum of the respondent's dichotomous "white" behaviors.

The sum of the respondent's "white" frequency behaviors after each is rescaled to have maximum 1 and minimum 0 .

= White Dichotomous + White Frequency

The sum of each respondent's dichotomous "black" behaviors.

The sum of each respondent's "black" frequency variables after each is rescaled to have maximum 1 and minimum 0 .

= Black Dichotomous + Black Frequency

= White Dichotomous $+\left(\mathrm{N}_{\mathrm{bD}}-\mathrm{Black}\right.$ Dichotomous $)$, where $\mathrm{N}_{\mathrm{bD}}$ is the number of "black" dichotomous behaviors

= White Frequency $+\left(\mathrm{N}_{\mathrm{bF}}-\mathrm{Black}\right.$ Frequency $)$, where $\mathrm{N}_{\mathrm{bF}}$ is the number of "black" frequency behaviors

= Aggregate Dichotomous + Aggregate Frequency

Table 6 reports summary statistics for the indices described in Table 5, for all five of our samples. Each samples' indices' components are defined based on that sample's column in Table 4b or 4c. For example, school_index is included in the "White" and "Aggregate" indices for the "all respondents" at-home sample (the third column of Table 4b), but not in the other two at-home samples because the regression coefficient on 
"black" is only significantly different from zero and negative in the "all respondents" regression, not in the other two in-school sample regressions.

The summary statistics reported in Table 6 show two important general relationships between the mixed-race populations and the monoracial populations. That is, although the mixed-race indices' means are closer to the white indices' means than to the black indices' means, yet the standard deviation of the mixed-race population's indices are generally larger than the black population's standard deviation and smaller than the white population's standard deviation. We noted similar features in the separate behaviors' means and standard deviations in Table 2, and we will see it again in the regression residuals reported in the next section.

With these aggregate indices in hand, we are now ready for the second stage of our analysis, classifying average mixed-race behavior in relationship to black and white monoracial behaviors. Table 7a reports regressions of the indices from Table 6 on the same explanatory variables as were used to generate Tables $4 \mathrm{a}$, $4 \mathrm{~b}$, and $4 \mathrm{c}$. The estimated coefficients on the control variables are again omitted for clarity and this table considers only our preferred sample (using parents' identification to determine the adolescent's identity). The first trivial result (in the row "Type of behavior") is to confirm that our aggregated indices maintain the underlying statistical test of significance of the black indicator variable, as depicted in Figure 1. All indices of white behaviors remain "white" types of behavior, all black index variables are "black" types of behavior, and the combined indices indicate "white" behavior, as each one should.

The row in Table 7a that reports our substantive results at this stage is labeled "Identity". Figure 2 describes the taxonomy and logic behind the "Identity" row, summarizing conditional average behavior of the mixed-race sub-population. The classifications are based on an ordering of the coefficients $\beta_{\text {mixed }}$ and $\beta_{\text {black }}$ relative to zero, as well as the statistical significance of their differences, implying seven possible "Identity" outcomes. All coefficients and p-values are reported in Table 7a for our preferred sample. Table $7 \mathrm{~b}$ reports similar results for all five samples, without the coefficients and p-values.

\section{Figure 2. Classifying biracial behavior, "Identity" in Tables $7 \mathrm{a}$ and $7 \mathrm{~b}$}

Using p-values and signs of coefficients on the black and mixed indicator variables 


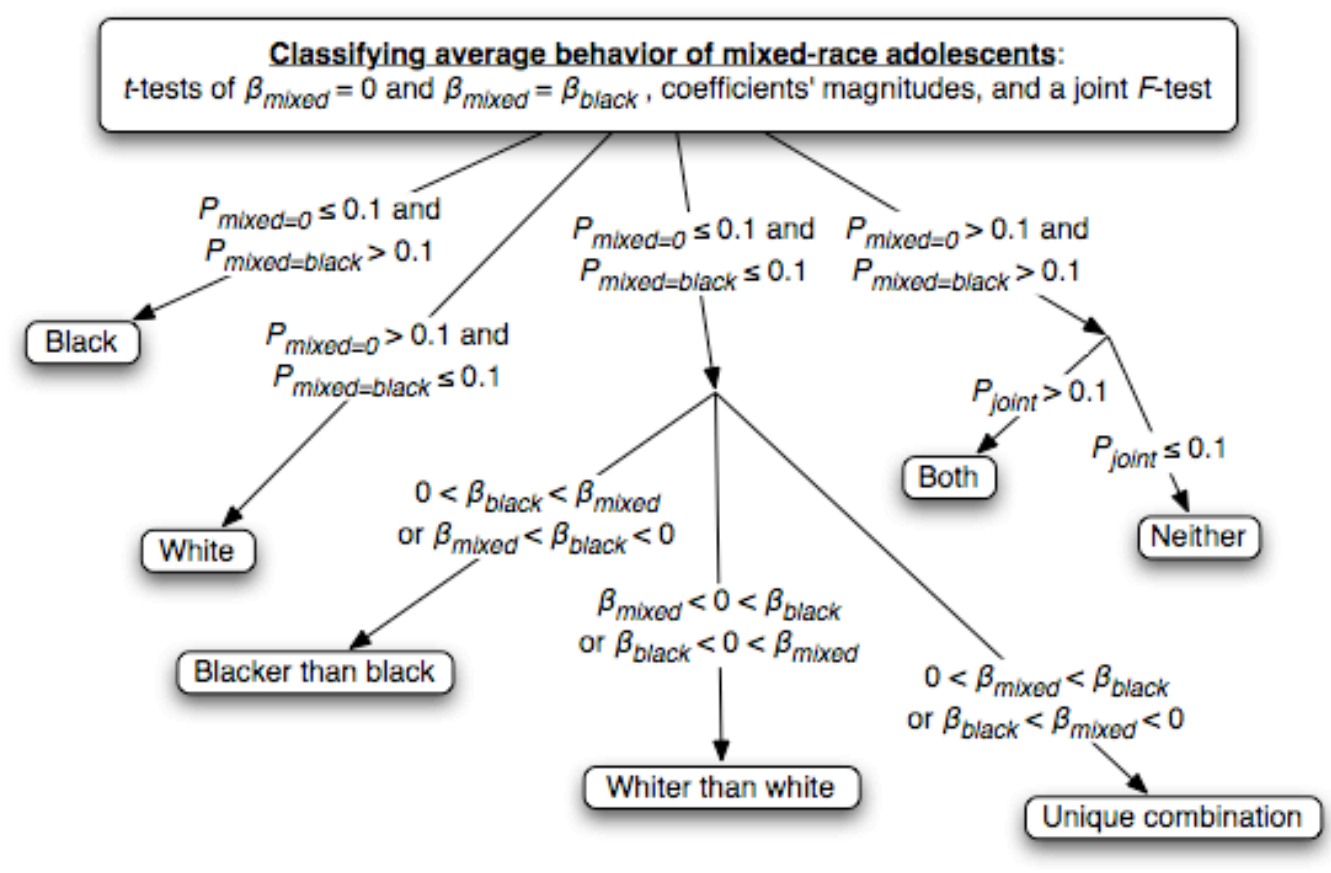

Remembering that the excluded racial category is white adolescents, the easiest cases to explain in Figure 2 are the first two from the left: "Black" and "White." Mixed-race adolescents are engaging in typically "Black" behaviors when the coefficient on the mixed-race indicator variable $\left(\beta_{\text {mixed }}\right)$ is statistically different from zero but is not statistically different from the estimated coefficient on the black indicator variable $\left(\beta_{\text {black }}\right)$. Mixed-race adolescents are engaging in typically "White" behaviors when the coefficient on mixed is not different from zero and it is statistically different from the coefficient on the black indicator variable.

(Although we use a $p$-value of 0.10 as our cutoff, Table 7 a shows that the $p$-values are seldom larger than 0.05 in our preferred sample, and this is true in the other samples as well.) The next three mixed-race behavioral characteristics, moving from the left to the right in Figure 2, are identified by ordering zero and the two racial coefficients $\beta_{\text {mixed }}$ and $\beta_{\text {black }}$ when all three are statistically different from each other. (The coefficient $\beta_{\text {black }}$ must be different from zero given our construction of the index.) In the case of "Blacker-than-black", the coefficient on the black indicator variable is greater than zero and the coefficient on mixed is larger than the black coefficient. In the case of "Whiter-than-white" behavior, the opposite ordering holds. We label the third case, when mixed lies between zero and black, "Unique Combination". The final two categories occur when the mixed indicator variable is not individually statistically different from either zero or the black indicator variable. If the joint $F$-test of these two null hypotheses is also not statistically significant, then we cannot 
reject the hypothesis that mixed-race behavior is either black or white, the "Both" case. If the joint test is statistically significant, then we have a result in which we can only say that average mixed-race behavior is "Neither" black nor white.

The empirical results summarized in the "Identity" row of Table 7a indicate that mixed-race adolescents' behaviors are not easily characterized and that their identities may be in flux. Although the results (in the first three columns) as regards "white" behaviors are not decisive for the frequency and dichotomous indices separately, once the two indices are combined, we see that mixed-race adolescents on average adopt white behaviors. The most robust result (in the second group of three columns) is that mixed-race youth follow black behaviors with respect to those behaviors that are typically black. Once the "black" and "white" indices are combined (in the last group of three columns,), the average behavior of mixed-race adolescents is statistically different from both black and white adolescents, a convex combination of the two identities, not behavior that is either "blacker than black" or "whiter than white".

The "Identity" rows of Table $7 \mathrm{~b}$ report results from all samples, first repeating the information from Table 7a, our preferred sample in which adolescent race is determined by the parents' races. Although race is more likely endogenous to identity and behavior in the other four samples, we can use those additional samples to investigate the robustness of our findings in our preferred sample. Interestingly, the two "Identity" rows that are most different from the others are the second and third samples from the in-home survey. We can speculate on two reasons for the discrepancy. Perhaps self-identification of race "whitens", or it may be that we are losing statistical significance in differentiation from the few black behaviors. Looking back at Table 1, we can find support for both these assertions: Moving from parent-defined to self-defined mixed-race excludes 17 who selfidentify as black, 7 as white, and 13 as other (a total of 37), but includes only an additional 8 (5 with black parents and 3 with white parents). So it may be that when mixed-race identification is endogenous to behavior, those selecting into mixed-race are more likely to be comfortable with a white identity. But this argument loses some force when considering the two in-school samples from Table $7 b$, because race is still self-identified but we have much larger sample sizes. See also the summary statistics in Tables A1 and A2 for sample sizes (after also including Wave 2 observations in the case of the in-home samples). 
These five samples lend strong support to the result that the average behavior of mixed-race teens generally follows a pattern of adopting both black and white behaviors. The result is a unique identity, one that is different from both the average behavior of white teens and the average behavior of black teens (conditional on our control measures, of course). This unique identity is a convex combination of the two identities, not evidenced by behavior that is either "blacker than black" or "whiter than white".

\section{7: Variance in mixed-race individual identities implied by relative variance in behavior}

As we noted earlier, an analysis of average behavior may conceal the fact that mixed-race individuals are experimenting with a wider range of identities. Certainly the previous section's discussion reveals important characteristics of mixed-race identity, but we can add more to our understanding of individual behavior by moving beyond a comparison of averages. To better understand the complexities of mixed-race behavioral choices and identities, we now consider the variance in residual errors across the three racial groups, comparing mixed-race adolescents to black and white adolescents in turn as well as comparing mixed-race adolescents to the monoracial (either black or white) group as a whole. The test statistics for equality of variance that we use are robust to non-normality, and we compute them using the robvar ( ) command in Stata ${ }^{\circledR}$ Version 10 (Brown and Forsythe 1974, Levene 1960). We use the several tests defined by those authors, and the statistical significance of the differences in variance between the subgroups were generally robust to the choice of statistical test.

Tables $7 \mathrm{a}$ and $7 \mathrm{~b}$ summarize the results in the rows labeled "Differences in stdev". The label "mix $>$ b" indicates, for example, that the variance in mixed-race adolescents' behaviors is greater than the variance in black adolescents' behaviors, while "mix > mono" compares the variance of mixed-race adolescents' behaviors relative to the group composed of all monoracial adolescents. Only statistically significant differences are reported. We again find evidence that mixed-race adolescents have less settled identities than do the monoracial adolescents: There is more variation in behavior, and thus in definition of identity, among the mixed-race adolescents, especially as compared to the black racial group. The intergroup differences in the 
residual intragroup variances are again suggestive of a mixed-race group whose behavioral norms are less well defined than for monoracial adolescents.

\section{8: Concluding comments}

In this research, we have expanded on the previous literature by considering the behavior and identity of mixed-race youth, adding several important new methods and findings. We do not rely solely upon selfreported race but make use of parental identification as our preferred measure of racial group membership. We also let the data determine which behaviors are black and which are white. The AddHealth survey allowed us to consider a broad range of behaviors and outcomes from a nationally representative data set with a rich set of control variables. Finally, we look at both average behavior and intragroup variance differences across the racial categories to learn more about individuals' choices.

Our results indicate that mixed-race youth act both white and black by adopting both types of behaviors, those that can be empirically characterized as "black" and those that can be characterized as "white". When we combine both types of behavior, average mixed-race behavior is a combination that is neither white nor black, and the variance in mixed-race behavior is generally greater than the variance in behavior of monoracial adolescents, especially as compared to the black racial group.

We thus find that mixed-race identities are less well established, codified, or enforced than are monoracial identities. Davis (1991) and Tizard and Phoenix (2002) provide anecdotal evidence supplied by mixed-race youth that they resent the demands placed on them to exhibit a kind of racial loyalty by conforming to prescribed norms and avoiding proscribed behaviors. In the terms of our theoretical model, both black and white racial salience are high among the nationally-represented group of adolescents in the AddHealth data, but the continued acceptance of the one-drop rule makes blackness somewhat more salient than whiteness. The salience of black and white identities among mixed-race adolescents are manifested in the group's conditional average behavior. But the racial ambivalence reported by mixed-race youth to other researchers manifests itself in our data as more highly variable intragroup behavior, measured by residual variance, as compared to monoracial youths generally but especially as compared to the black group. 
Given that adolescence is the time during which there is most pressure to establish an identity, and that our results indicate that mixed-race youth are finding their own identities, not necessarily "joining” either monoracial group, but in another sense joining both of them, one interpretation of our results is that multiracial youth have the freedom to embrace both of their racial identities. We have found behaviors, providing evidence of identities, that are more complex that those described in current interpretations of the "acting white" hypothesis. The predominant application of "acting white" in the literature has been in the context of academic achievement, and the next step in our research is to investigate the regularities we have uncovered here in that more complex context. 


\section{Appendix: Samples in which the adolescent's race is self-identified}

Although our preferred sample provided a measure of identity that is arguably exogenous to students' behaviors, it was necessarily limited to intact families. We then repeated our analyses, widening the sample to include all families and using adolescents' self-reported race. We first used the at-home data from Waves 1 and 2 which allows us to keep the same outcome variables, beginning with our sample of intact families but switching the racial indentification from parents' race(s) to the adolescent's self identification (the sample size falls slightly because there were some who didn't choose either black or white but had parents who did), and then expanding the sample by dropping the requirement that the adolescents be in intact families. The summary statistics for these two samples' dependent variables are reported in Table A1 and for their control variables in Table A3, matching those in Table 3. We then consider the much larger sample of students from the inschool survey, which was considerably shorter and did not ask many of the behavior questions that were in that at-home Waves 1 and 2. Thus, we have no questions about sexual activity or drug use in Table A2's summary statistics of dependent variables. Even the set of explanatory variables is not identical as can be seen

in Table A4. We can only use the adolescent self-report of race(s) since the parent race data is not available for the in-school sample. The two samples we create from the in-school data are for "intact" families and for all respondents. (Given the structure of this questionnaire, we cannot be sure that the two parent families are intact biological families, although we do at least delete those adolescents who report having been adopted.) Our analysis proceeds with these samples as with the preferred sample. In particular, the "black" and "white" behavior indices are constructed separately for each sample. Yet there is considerable agreement across samples in the results of Tables $4 b, 4 c$, and $7 b$. 


\section{References}

Akerlof, George A. and Rachel E. Kranton. 2000. "Economics and Identity.” Quarterly Journal of Economics 115 (August), 715-753.

Akerlof, George A. and Rachel E. Kranton. 2002. "Identity and Schooling: Some Lessons for the Economics of Education." Journal of Economic Literature 40 (December), 1167-1201.

Archer, Sally L. 1982. “The Lower Age Boundaries of Identity Development.” Child Development 53:6 (December), 1551-1556.

Austen-Smith, David and Roland G. Fryer, Jr. 2005. “An Economic Analysis of 'Acting White."” Quarterly Journal of Economics 120 (month), 551-583.

Benjamin, Daniel J., James J. Choi, and A. Joshua Strickland. 2007. “Social Identity and Preferences.” NBER working paper no. 13309 (August).

Bodenhorn, H. and C. S. Ruebeck. 2003. "The economics of identity and the endogeneity of race.” NBER working paper no. 9962 (September).

Brown, M. B., and A. B. Forsythe. 1974. "Robust Test for the Equality of Variances." Journal of the American Statistical Association 69: 364-367.

Bryson, Ken. 1995. "Household and Family Characteristics: March 1996.” Current Population Reports, Population Characteristics. Accessed at http://www.census.gov/prod/2/pop/p20/p20-488.pdf.

Daniel, G. Reginald. 1996. "Black and White Identity in the New Millennium: Unsevering the Ties that Bind." In The Multiracial Experience: Racial Borders at the New Frontier, pp. 121-139. Edited by Maria P. P. Root. Thousand Oaks, Ca.: Sage Publications.

Darity, William A., Jr., Patrick L. Mason, and James B. Stewart. 2006. "The Economics of Identity: The Origin and Persistence of Racial Identity Norms.” Journal of Economic Behavior \& Organization 60 (month), 283-305.

Davis, F. James. 1991. Who Is Black? One Nation's Definition. University Park, PA: Pennsylvania State University Press. 
Erikson, E. H. 1968. Identity: Youth and Crisis. New York: Norton.

Ferguson, Ronald F. 2006. "New Evidence on Why Black High Schoolers Get Accused of 'Acting White?"”

Research Brief: Achievement Gap Initiative at Harvard University (September).

Fordham, Signithia and John U. Ogbu. 1986. "Black Students' School Success: Coping with the Burden of

'Acting White'.” The Urban Review 18 (month), 176-206.

Fryer, Roland G., Jr. 2007. “Guess Who’s Been Coming to Dinner? Trends in Interracial Marriage over the $20^{\text {th }}$ Century. Journal of Economic Perspectives 21:2 (Spring 2007), 71-90.

Fryer, Roland G., Jr. and Paul Torelli. 2005. “An Empirical Analysis of 'Acting White.'” Review of Economics and Statistics no (month), pages.

Furstenberg, Frank F. 2000. "The Sociology of Adolescence and Youth in the 1990s" A Critical Commentary." Journal of Marriage and the Family 62:4 (November), 896-910.

Goldsmith, Arthur H., Darrick Hamilton, and William Darity, Jr. 2007. "From Dark to Light: Skin Color and Wages among African-Americans.” Journal of Human Resources 42(4): 701-738.

Gyimah-Brempong, Kwabena and Gregory Price. 2006. “Crime and Punishment: And Skin Hue Too?” American Economic Review 96 (May), 246-250.

Harris, David R. 2001. "Does it Matter How We Measure? Racial Classification and the Characteristics of Multiracial Youth. Working paper, University of Michigan (March).

Harris, David R. 2002. "In the Eye of the Beholder: Observed Race and Observer Characteristics.” PSC Research Report No. 02-522. Population Studies Center, University of Michigan (August).

Harris, David R. and Jeremiah Joseph Sim. 2002. "Who Is Multiracial? Assessing the Complexity of Lived Race.” American Sociological Review 67 (August), 614-627.

Harris, David R. and Justin L. Thomas. 2002. "The Educational Costs of Being Multiracial: Evidence from a National Survey of Adolescents.” PSC Research Report No. 02-521. Population Studies Center, University of Michigan (August).

Herman, Melissa. 2002. "The Black-White-Other Test Score Gap: Academic Achievement among Mixed-Race Adolescents.” Northwestern University, Institute for Policy Research working paper no. 02-31 (month). 
Hitlin, S., Elder, G., and J. Scott Brown. 2006. "Racial Self-Categorization in Adolescent: Multiracial

Development and Social Pathways.” Child Development. 77(5):1298-1308.

Joyner, Kara and Grace Kao. 2005. "Interracial Relationships and the Transition to Adulthood.” American Sociological Review 70 (August), 563-581.

Kao, Grace. 1999. "Racial Identity and Academic Performance: An Examination of Biracial Asian and African American Youth.” Journal of Asian American Studies 2 (month), 223-249.

Kennedy, Randall. 2003. Interracial Intimacies: Sex, Marriage, Identity, and Adoption. New York: Pantheon Books.

Levene, H. 1960. "Robust Tests for Equality of Variances.” In Contributions of Probability and Statistics: Essays in Honor of Harold Hotelling. ed. I. Olkin, S. G. Ghurye, W. Hoeffding, W. G. Madow, and H. B. Mann, 278-292. Menlo Park, CA: Stanford University Press.

McLanahan, Sara and Gary Sandefur. 1994. Growing Up with a Single Parent: What Hurts, What Helps. Cambridge, Mass., press.

National Youth Risk Behavior Survey: 2005.

http://www.cdc.gov/HealthyYouth/yrbs/pdf/subgroup/2005YRBSRaceEthnicitySubgroup.pdf. Accessed December 15, 2007.

Park, Robert E. 1928. "Human Migration and the Marginal Man,” American Journal of Sociology 33 (month), 881-895.

Park, Robert E. 1931. “Mentality of Racial Hybrids,” American Journal of Sociology 36 (month), 534-551. Rangel, Marcos. 2007. "Is Parental Love Colorblind? Allocation of Resources within Mixed-Race Families." Unpublished working paper, University of Chicago (May).

Resnick, M.D., Bearman, P.S., Blum, R.W., Bauman, K.E., Harris, K.M., Jones, J., Tabor, J., Beurring, T., Sieving, R.E., Shew, M., Ireland, M., Bearninger, L.H., and Udry, J.R. 1997. "Protesting Adolescents from Harm. Findings from the National Longitudinal Study on Adolescent Health.” Journal of the American Medical Association, 278, 823-32. 
Romano, Renee. 2003. Race Mixing: Black-White Marriage in Post-War America. Cambridge, Mass.: Harvard University Press.

Rosenfeld, Michael J. and Byung-Soo Kim. 2005. "The Independence of Young Adults and the Rise of Interracial and Same-Sex Unions,” American Sociological Review 70 (August), 541-562.

Stevenson, Betsy and Justin Wolfers. "Marriage and Divorce: Changes and their Driving Forces," Journal of Economic Perspectives, 21(2) Spring 2007.

Stonequist, E. V. 1937. The Marginal Man: A Study in Personality and Culture Conflict. New York: Scribners.

Tizard, Barbara and Ann Phoenix. 2002. Black, White or Mixed Race? Race and Racism in the Lives of Young People of Mixed Parentage. Revised edition. London and New York: Routledge Press.

Tyson, Karolyn and William Darity, Jr. 2005. “It's Not 'a Black Thing': Understanding the Burden of Acting White and Other Dilemmas of High Achievement.” American Sociological Review 70 (August), 582605.

Udry, Richard, Rose Maria Li, and Janet Hendrickson-Smith. 2003. "Health and Behavior Risks of Adolescents with Mixed-Race Identity.” American Journal of Public Health 93 (November), 1865-1870. 
ever been a regular cigarette smoker

smoked cigarettes in past 30 days

smoked on 15 or more days in past month

ever smoked marijuana

ever used other drugs

drank alcohol at least once in past month

had five or more drinks in a row at least oonce in past year

drank weekly or more often in past year

ever had sexual intercourse

suspended at least once in past year

ever been expelled from school

number of times skipped school w/o excuse in past year

Questions below pertain to the current school year

reported feeling close to people at school

reported feeling part of the school

reported that students at school are prejudiced

reported that school is safe

reported that they are happy to be at their school

reported that they believe teachers are fair at their school

Index of the above 6 items (higher: more satisified with school)

reported having trouble with teachers

reported having trouble paying attention in school

reported trouble with getting homework done

reported trouble getting along with other students

index of school troubles from 4 above items (higher: more troubles)

graffiti=1 if painted graffiti in past year

property=If damaged property

lie $=1$ if lied to parents about whereabouts or who with

steal $=1$ if ever stolen anything

drive_wo=1 if driven a car w/o permission

ever entered a building/house to steal something

ever stolen something worth over $\$ 50$

ever stolen something worth less than $\$ 50$

every behaved rowdy or badly in public

index of delinquency created from above 9 items

Questions below pertain to the previous week in reference to the survey week

housework=1 if reported doing housework last week

\# of hours watched videos last week

\# hours played video or computer games last week

\# of hours listened to the radio last week

how many hours did you watch tv last week

engaged in hobbies last week

watched tv or played video games last week

rollerskated, rollerbladed, bicycles or skateboarded last week

played sports last week

exercised last week

hung out with friends last weekend

\begin{tabular}{|c|c|c|c|c|c|c|}
\hline \multirow[b]{2}{*}{ Variable } & \multicolumn{2}{|c|}{ Black and White } & \multicolumn{2}{|c|}{ Black } & \multicolumn{2}{|c|}{ White } \\
\hline & Obs & $\begin{array}{l}\text { Mean } \\
\text { (Std) }\end{array}$ & Obs & $\begin{array}{c}\text { Mean } \\
\text { (Std) }\end{array}$ & Obs & $\begin{array}{l}\text { Mean } \\
\text { (Std) }\end{array}$ \\
\hline smoker & 106 & 0.170 & 1587 & 0.050 & 9622 & 0.195 \\
\hline smoke_30 & 106 & 0.245 & 1579 & 0.111 & 9578 & 0.295 \\
\hline smoker_reg & 106 & 0.104 & 1588 & 0.016 & 9625 & 0.153 \\
\hline pot & 106 & 0.189 & 1559 & 0.108 & 9504 & 0.160 \\
\hline odrugs & 106 & 0.009 & 1570 & 0.006 & 9556 & 0.038 \\
\hline drank12 & 106 & 0.406 & 1584 & 0.283 & 9617 & 0.469 \\
\hline drunken & 106 & 0.179 & 1585 & 0.103 & 9615 & 0.288 \\
\hline drank_weekly & 106 & 0.123 & 1588 & 0.103 & 9625 & 0.131 \\
\hline hadsex & 104 & 0.471 & 1573 & 0.446 & 9549 & 0.300 \\
\hline suspend & 101 & 0.139 & 1559 & 0.235 & 9438 & 0.129 \\
\hline expelled & 101 & 0.020 & 1558 & 0.036 & 9439 & 0.014 \\
\hline school_skip & 106 & $\begin{array}{l}1.792 \\
(7.708)\end{array}$ & 1587 & $\begin{array}{l}0.799 \\
(2.654)\end{array}$ & 9611 & $\begin{array}{l}1.216 \\
(4.819)\end{array}$ \\
\hline feelclose & 106 & 0.755 & 1588 & 0.819 & 9625 & 0.868 \\
\hline partschool & 106 & 0.840 & 1588 & 0.863 & 9625 & 0.879 \\
\hline prejudiced & 106 & 0.660 & 1588 & 0.528 & 9625 & 0.702 \\
\hline safe at school & 106 & 0.783 & 1588 & 0.825 & 9625 & 0.885 \\
\hline happyschool & 106 & 0.736 & 1588 & 0.805 & 9625 & 0.852 \\
\hline teachfaird & 106 & 0.736 & 1588 & 0.761 & 9625 & 0.803 \\
\hline school_index & 97 & $\begin{array}{l}0.995 \\
(0.454)\end{array}$ & 1546 & $\begin{array}{l}0.896 \\
(0.462)\end{array}$ & 9338 & $\begin{array}{l}0.878 \\
(0.443)\end{array}$ \\
\hline tchr_trouble & 106 & 0.632 & 1588 & 0.559 & 9625 & 0.576 \\
\hline pay_attnd & 106 & 0.736 & 1588 & 0.669 & 9625 & 0.786 \\
\hline homeworkd & 106 & 0.698 & 1588 & 0.627 & 9625 & 0.720 \\
\hline getalongd & 106 & 0.594 & 1588 & 0.569 & 9625 & 0.596 \\
\hline schtrouble_index & 99 & $\begin{array}{l}0.879 \\
(0.534)\end{array}$ & 1548 & $\begin{array}{l}0.776 \\
(0.509)\end{array}$ & 9365 & $\begin{array}{l}0.874 \\
(0.509)\end{array}$ \\
\hline graffiti & 106 & 0.123 & 1577 & 0.047 & 9581 & 0.075 \\
\hline property & 106 & 0.208 & 1577 & 0.107 & 9583 & 0.172 \\
\hline lie & 106 & 0.491 & 1575 & 0.502 & 9583 & 0.503 \\
\hline steal & 106 & 0.245 & 1573 & 0.186 & 9580 & 0.197 \\
\hline drive_wo & 106 & 0.094 & 1578 & 0.082 & 9585 & 0.078 \\
\hline enter_steal & 106 & 0.066 & 1586 & 0.033 & 9616 & 0.037 \\
\hline steal_over50 & 106 & 0.047 & 1578 & 0.025 & 9587 & 0.037 \\
\hline steal_less50 & 106 & 0.217 & 1578 & 0.129 & 9583 & 0.172 \\
\hline bad_pupublic & 106 & 0.443 & 1576 & 0.413 & 9582 & 0.454 \\
\hline delinq_index & 106 & $\begin{array}{l}0.314 \\
(0.387)\end{array}$ & 1563 & $\begin{array}{l}0.214 \\
(0.286)\end{array}$ & 9552 & $\begin{array}{l}0.245 \\
(0.327)\end{array}$ \\
\hline housework & 106 & 0.981 & 1588 & 0.964 & 9625 & 0.970 \\
\hline video & 106 & $\begin{array}{l}5.858 \\
(10.331)\end{array}$ & 1585 & $\begin{array}{l}5.833 \\
(9.052)\end{array}$ & 9621 & $\begin{array}{l}3.688 \\
(5.652)\end{array}$ \\
\hline computer_games & 106 & $\begin{array}{l}3.019 \\
(6.290)\end{array}$ & 1586 & $\begin{array}{l}3.484 \\
(7.773)\end{array}$ & 9625 & $\begin{array}{l}2.330 \\
(5.513)\end{array}$ \\
\hline radio & 106 & $\begin{array}{l}11.708 \\
(11.402)\end{array}$ & 1586 & $\begin{array}{l}16.145 \\
(20.020)\end{array}$ & 9601 & $\begin{array}{l}15.432 \\
(18.419)\end{array}$ \\
\hline watchtv & 106 & $\begin{array}{l}21.000 \\
(17.728)\end{array}$ & 1578 & $\begin{array}{l}20.561 \\
(18.81)\end{array}$ & 9599 & $\begin{array}{l}13.228 \\
(12.361)\end{array}$ \\
\hline hobbies & 106 & 0.821 & 1588 & 0.795 & 9624 & 0.841 \\
\hline tv_video & 106 & 0.981 & 1588 & 0.979 & 9625 & 0.969 \\
\hline skating & 106 & 0.349 & 1588 & 0.299 & 9625 & 0.424 \\
\hline sports & 106 & 0.726 & 1588 & 0.664 & 9625 & 0.751 \\
\hline exceercise & 106 & 0.764 & 1588 & 0.851 & 9624 & 0.838 \\
\hline hangfriends & 106 & 0.943 & 1588 & 0.899 & 9624 & 0.932 \\
\hline
\end{tabular}


Table 3: Control variables, at-home sample (waves $1 \&$ 2)

Income \$

Age

Female

Urban residence

Rural residence

Parent college graduate

Catholic

No religion

Age of mom in years

Age of dad in years

Mom born in US

Dad born in US

Dad's job is management/professional

Dad's job other than management/professional

Dad has no job

Mom's job is management/professional

Mom's job other than management professional

Mom has no job

Parent receives welfare
Parents' id race, intact families

\begin{tabular}{lrlrlr}
\multicolumn{2}{c}{ Black/white } & \multicolumn{2}{c}{ Black } & \multicolumn{2}{c}{ White } \\
\hline Obs & $\begin{array}{c}\text { Mean } \\
\text { (Std) }\end{array}$ & Obs & $\begin{array}{c}\text { Mean } \\
\text { (Std) }\end{array}$ & Obs & \multicolumn{1}{c}{$\begin{array}{l}\text { Mean } \\
\text { (Std) }\end{array}$} \\
106 & $\begin{array}{r}\text { 41.000 } \\
\text { (28.236) }\end{array}$ & & $\begin{array}{r}42.179 \\
(35.975)\end{array}$ & 9614 & 51.005 \\
& $(28.251 .182)$ \\
105 & 15.838 & 1587 & 15.639 & 9624 & 15.688 \\
& $(1.760)$ & & $(1.694)$ & & $(1.666)$ \\
106 & 0.434 & 1588 & 0.550 & 9625 & 0.501 \\
106 & 0.528 & 1588 & 0.424 & 9625 & 0.252 \\
106 & 0.113 & 1588 & 0.275 & 9625 & 0.308 \\
106 & 0.368 & 1588 & 0.395 & 9625 & 0.369 \\
106 & 0.236 & 1588 & 0.047 & 9625 & 0.300 \\
106 & 0.104 & 1588 & 0.025 & 9625 & 0.058 \\
106 & 42.500 & 1588 & 42.252 & 9625 & 41.730 \\
& $(5.471)$ & & $(5.625)$ & & $(5.022)$ \\
106 & 48.547 & 1588 & 45.157 & 9625 & 44.306 \\
& $(7.920)$ & & $(6.550)$ & & $(5.923)$ \\
106 & 0.755 & 1588 & 0.930 & 9625 & 0.886 \\
106 & 0.764 & 1588 & 0.941 & 9625 & 0.889 \\
106 & 0.217 & 1588 & 0.203 & 9625 & 0.265 \\
106 & 0.689 & 1588 & 0.729 & 9625 & 0.699 \\
106 & 0.094 & 1588 & 0.059 & 9625 & 0.033 \\
106 & 0.311 & 1588 & 0.363 & 9625 & 0.279 \\
106 & 0.509 & 1588 & 0.509 & 9625 & 0.589 \\
106 & 0.179 & 1588 & 0.125 & 9625 & 0.130 \\
106 & 0.094 & 1588 & 0.061 & 9625 & 0.039
\end{tabular}


Table 4a: Classification of behavior by monoracial group (at-home sample, parents' race)

\begin{tabular}{|c|c|c|c|c|c|c|c|c|c|c|c|c|}
\hline $\begin{array}{l}\text { Dependent variable } \rightarrow \\
\text { black }\end{array}$ & $\begin{array}{l}\text { smoker } \\
-0.144^{* *}\end{array}$ & $\begin{array}{l}\text { smoke_30 } \\
-0.174^{\star \star}\end{array}$ & $\begin{array}{l}\text { smoke_reg } \\
-0.134^{\star \star}\end{array}$ & $\begin{array}{l}\text { pot } \\
-0.0423^{* *}\end{array}$ & $\begin{array}{l}\text { odrugs } \\
-0.0276^{* *}\end{array}$ & $\begin{array}{l}\text { drank12 } \\
-0.137^{* *}\end{array}$ & $\begin{array}{l}\text { drunken } \\
-0.147^{* *}\end{array}$ & $\begin{array}{l}\text { drank_weekly } \\
-0.0290^{*}\end{array}$ & $\begin{array}{l}\text { hadsex } \\
0.113^{\star *}\end{array}$ & $\begin{array}{l}\text { suspend } \\
0.0532^{* *}\end{array}$ & $\begin{array}{l}\text { expelled } \\
0.00468\end{array}$ & $\begin{array}{l}\text { school_skip } \\
-0.598^{\star \star}\end{array}$ \\
\hline & {$[0.011]$} & {$[0.014]$} & {$[0.0088]$} & {$[0.012]$} & {$[0.0044]$} & {$[0.017]$} & {$[0.013]$} & {$[0.011]$} & {$[0.016]$} & {$[0.013]$} & {$[0.0057]$} & {$[0.14]$} \\
\hline mixed & $\begin{array}{l}-0.0159 \\
{[0.035]}\end{array}$ & $\begin{array}{l}-0.0285 \\
{[0.042]}\end{array}$ & $\begin{array}{l}-0.0358 \\
{[0.031]}\end{array}$ & $\begin{array}{l}0.0339 \\
{[0.037]}\end{array}$ & $\begin{array}{l}-0.0226^{*} \\
{[0.010]}\end{array}$ & $\begin{array}{l}-0.0677 \\
{[0.043]}\end{array}$ & $\begin{array}{l}-0.116^{* *} \\
{[0.035]}\end{array}$ & $\begin{array}{l}-0.00993 \\
{[0.033]}\end{array}$ & $\begin{array}{l}0.160^{* *} \\
{[0.044]}\end{array}$ & $\begin{array}{l}-0.0337 \\
{[0.034]}\end{array}$ & $\begin{array}{l}-0.00452 \\
{[0.014]}\end{array}$ & $\begin{array}{l}0.266 \\
{[0.74]}\end{array}$ \\
\hline Constant & $\begin{array}{l}-1.241^{* *} \\
{[0.26]}\end{array}$ & $\begin{array}{l}-1.670^{* *} \\
{[0.32]}\end{array}$ & $\begin{array}{l}-0.950^{* *} \\
{[0.23]}\end{array}$ & $\begin{array}{l}-0.883^{* *} \\
{[0.26]}\end{array}$ & $\begin{array}{l}-0.307^{*} \\
{[0.13]}\end{array}$ & $\begin{array}{l}-2.570^{* *} \\
{[0.36]}\end{array}$ & $\begin{array}{l}-1.326^{* \star} \\
{[0.31]}\end{array}$ & $\begin{array}{l}-0.680^{* *} \\
{[0.24]}\end{array}$ & $\begin{array}{l}-0.818^{*} \\
{[0.32]}\end{array}$ & $\begin{array}{l}-1.083^{* *} \\
{[0.28]}\end{array}$ & $\begin{array}{l}-0.165+ \\
{[0.093]}\end{array}$ & $\begin{array}{l}-1.492 \\
{[3.40]}\end{array}$ \\
\hline Observations & 11301 & 11249 & 11305 & 11155 & 11218 & 11293 & 11292 & 11305 & 11212 & 11084 & 11084 & 11290 \\
\hline Type of behavior & white & white & white & white & white & white & white & white & black & black & neither & white \\
\hline Dependent variable $\rightarrow$ & feelclose & partschoold & prejudicedd & safe at school & happyschool & teachfaird & school_index & tchr_trouble & pay_attnd & homeworkd & getalongd & schtrouble_index \\
\hline black & $\begin{array}{l}-0.0433^{* *} \\
{[0.014]}\end{array}$ & $\begin{array}{l}-0.0123 \\
{[0.013]}\end{array}$ & $\begin{array}{l}-0.0949^{* *} \\
{[0.017]}\end{array}$ & $\begin{array}{l}-0.00379 \\
{[0.014]}\end{array}$ & $\begin{array}{l}-0.0547^{* *} \\
{[0.015]}\end{array}$ & $\begin{array}{l}-0.0424^{\star *} \\
{[0.015]}\end{array}$ & $\begin{array}{l}0.0127 \\
{[0.017]}\end{array}$ & $\begin{array}{l}-0.0114 \\
{[0.018]}\end{array}$ & $\begin{array}{l}-0.0648^{* *} \\
{[0.016]}\end{array}$ & $\begin{array}{l}-0.0609^{\star *} \\
{[0.017]}\end{array}$ & $\begin{array}{l}-0.0166 \\
{[0.018]}\end{array}$ & $\begin{array}{l}-0.0525^{\star *} \\
{[0.019]}\end{array}$ \\
\hline mixed & $\begin{array}{l}-0.107^{\star} \\
{[0.042]}\end{array}$ & $\begin{array}{l}-0.0316 \\
{[0.035]}\end{array}$ & $\begin{array}{l}-0.000672 \\
{[0.046]}\end{array}$ & $\begin{array}{l}-0.0608 \\
{[0.039]}\end{array}$ & $\begin{array}{l}-0.120^{\star *} \\
{[0.041]}\end{array}$ & $\begin{array}{l}-0.0735+ \\
{[0.042]}\end{array}$ & $\begin{array}{l}0.113^{*} \\
{[0.044]}\end{array}$ & $\begin{array}{l}0.0596 \\
{[0.049]}\end{array}$ & $\begin{array}{l}-0.0248 \\
{[0.044]}\end{array}$ & $\begin{array}{l}-0.0327 \\
{[0.045]}\end{array}$ & $\begin{array}{l}0.0213 \\
{[0.048]}\end{array}$ & $\begin{array}{l}0.0118 \\
{[0.052]}\end{array}$ \\
\hline Constant & $\begin{array}{l}-0.174 \\
{[0.29]}\end{array}$ & $\begin{array}{l}-0.332 \\
{[0.27]}\end{array}$ & $\begin{array}{l}-2.930^{\star *} \\
{[0.40]}\end{array}$ & $\begin{array}{l}-0.326 \\
{[0.28]}\end{array}$ & $\begin{array}{l}-0.105 \\
{[0.31]}\end{array}$ & $\begin{array}{l}0.329 \\
{[0.34]}\end{array}$ & $\begin{array}{l}-1.257^{\star \star} \\
{[0.36]}\end{array}$ & $\begin{array}{l}0.213 \\
{[0.41]}\end{array}$ & $\begin{array}{l}-0.576 \\
{[0.37]}\end{array}$ & $\begin{array}{l}-0.183 \\
{[0.38]}\end{array}$ & $\begin{array}{l}1.093^{\star *} \\
{[0.41]}\end{array}$ & $\begin{array}{l}-1.731^{* \star} \\
{[0.44]}\end{array}$ \\
\hline Observations & 11305 & 11305 & 11305 & 11305 & 11305 & 11305 & 10967 & 11305 & 11305 & 11305 & 11305 & 10998 \\
\hline Type of behavior & white & neither & white & neither & white & white & neither & neither & white & white & neither & white \\
\hline $\begin{array}{l}\text { Dependent variable } \rightarrow \\
\text { black }\end{array}$ & $\begin{array}{l}\text { graffiti } \\
-0.0227^{* *} \\
{[0.0088]}\end{array}$ & $\begin{array}{l}\text { property } \\
-0.0367^{* *} \\
{[0.012]}\end{array}$ & $\begin{array}{l}\text { lie } \\
0.00998 \\
{[0.018]}\end{array}$ & $\begin{array}{l}\text { steal } \\
-0.00613 \\
{[0.015]}\end{array}$ & $\begin{array}{l}\text { drive_wo } \\
0.00924 \\
{[0.010]}\end{array}$ & $\begin{array}{l}\text { enter_steal } \\
-0.00648 \\
{[0.0067]}\end{array}$ & $\begin{array}{l}\text { steal_over50 } \\
-0.0142^{*} \\
{[0.0062]}\end{array}$ & $\begin{array}{l}\text { steal_less50 } \\
-0.0364^{\star *} \\
{[0.013]}\end{array}$ & $\begin{array}{l}\text { bad_public } \\
-0.00238 \\
{[0.018]}\end{array}$ & $\begin{array}{l}\text { delinq_index } \\
-0.0174 \\
{[0.011]}\end{array}$ & & \\
\hline mixed & $\begin{array}{l}0.0327 \\
{[0.032]}\end{array}$ & $\begin{array}{l}0.0347 \\
{[0.039]}\end{array}$ & $\begin{array}{l}-0.0252 \\
{[0.049]}\end{array}$ & $\begin{array}{l}0.0378 \\
{[0.043]}\end{array}$ & $\begin{array}{l}0.0134 \\
{[0.029]}\end{array}$ & $\begin{array}{l}0.0256 \\
{[0.024]}\end{array}$ & $\begin{array}{l}0.00425 \\
{[0.021]}\end{array}$ & $\begin{array}{l}0.0286 \\
{[0.040]}\end{array}$ & $\begin{array}{l}-0.00994 \\
{[0.047]}\end{array}$ & $\begin{array}{l}0.0523 \\
{[0.038]}\end{array}$ & & \\
\hline Constant & $\begin{array}{l}-0.336+ \\
{[0.20]}\end{array}$ & $\begin{array}{l}-0.840^{\star \star} \\
{[0.29]}\end{array}$ & $\begin{array}{l}-3.584^{\star \star} \\
{[0.40]}\end{array}$ & $\begin{array}{l}-1.139^{\star \star} \\
{[0.32]}\end{array}$ & $\begin{array}{l}-1.627^{\star \star} \\
{[0.20]}\end{array}$ & $\begin{array}{l}-0.187 \\
{[0.16]}\end{array}$ & $\begin{array}{l}-0.366^{\star *} \\
{[0.13]}\end{array}$ & $\begin{array}{l}-1.292^{\star \star} \\
{[0.28]}\end{array}$ & $\begin{array}{l}-1.39]^{* *} \\
{[0.41]}\end{array}$ & $\begin{array}{l}-1.731^{* \star} \\
{[0.26]}\end{array}$ & & \\
\hline $\begin{array}{l}\text { Observations } \\
\text { Type of behavior }\end{array}$ & $\begin{array}{l}11250 \\
\text { white }\end{array}$ & $\begin{array}{l}11252 \\
\text { white }\end{array}$ & $\begin{array}{l}11250 \\
\text { neither }\end{array}$ & $\begin{array}{l}11245 \\
\text { neither }\end{array}$ & $\begin{array}{l}11255 \\
\text { neither }\end{array}$ & $\begin{array}{l}11294 \\
\text { neither }\end{array}$ & $\begin{array}{l}11257 \\
\text { white }\end{array}$ & $\begin{array}{l}11253 \\
\text { white }\end{array}$ & $\begin{array}{l}11250 \\
\text { neither }\end{array}$ & $\begin{array}{l}11206 \\
\text { neither }\end{array}$ & & \\
\hline $\begin{array}{l}\text { Dependent variable } \rightarrow \\
\text { black }\end{array}$ & $\begin{array}{l}\text { housework } \\
-0.00347 \\
{[0.0070]}\end{array}$ & $\begin{array}{l}\text { video } \\
2.110^{\star *} \\
{[0.32]}\end{array}$ & $\begin{array}{l}\text { computer_games } \\
0.974^{\star \star} \\
{[0.26]}\end{array}$ & $\begin{array}{l}\text { radio } \\
0.891 \\
{[0.73]}\end{array}$ & $\begin{array}{l}\text { watchtv } \\
5.954^{\star *} \\
{[0.60]}\end{array}$ & $\begin{array}{l}\text { hobbies } \\
-0.0220 \\
{[0.014]}\end{array}$ & $\begin{array}{l}\text { tv_video } \\
0.00487 \\
{[0.0057]}\end{array}$ & $\begin{array}{l}\text { skating } \\
-0.0756^{\star *} \\
{[0.016]}\end{array}$ & $\begin{array}{l}\text { sports } \\
-0.0399^{*} \\
{[0.016]}\end{array}$ & $\begin{array}{l}\text { exercise } \\
0.0187 \\
{[0.013]}\end{array}$ & $\begin{array}{l}\text { hangfriends } \\
-0.0224^{*} \\
{[0.010]}\end{array}$ & \\
\hline mixed & $\begin{array}{l}0.0196 \\
{[0.014]}\end{array}$ & $\begin{array}{l}2.305^{*} \\
{[1.02]}\end{array}$ & $\begin{array}{l}0.474 \\
{[0.59]}\end{array}$ & $\begin{array}{l}-3.655^{\star \star} \\
{[1.20]}\end{array}$ & $\begin{array}{l}6.538^{* *} \\
{[1.71]}\end{array}$ & $\begin{array}{l}-0.0368 \\
{[0.038]}\end{array}$ & $\begin{array}{l}0.00788 \\
{[0.014]}\end{array}$ & $\begin{array}{l}-0.0439 \\
{[0.046]}\end{array}$ & $\begin{array}{l}0.00791 \\
{[0.043]}\end{array}$ & $\begin{array}{l}-0.0790+ \\
{[0.042]}\end{array}$ & $\begin{array}{l}0.0124 \\
{[0.022]}\end{array}$ & \\
\hline Constant & $\begin{array}{l}0.981^{* *} \\
{[0.14]}\end{array}$ & $\begin{array}{l}6.810 \\
{[5.98]}\end{array}$ & $\begin{array}{l}16.27^{\star *} \\
{[5.57]}\end{array}$ & $\begin{array}{l}-57.30^{\star \star} \\
{[14.5]}\end{array}$ & $\begin{array}{l}26.57^{*} \\
{[12.1]}\end{array}$ & $\begin{array}{l}1.216^{* *} \\
{[0.30]}\end{array}$ & $\begin{array}{l}0.924^{\star \star} \\
{[0.14]}\end{array}$ & $\begin{array}{l}3.277^{\star *} \\
{[0.39]}\end{array}$ & $\begin{array}{l}0.576+ \\
{[0.34]}\end{array}$ & $\begin{array}{l}0.766^{*} \\
{[0.30]}\end{array}$ & $\begin{array}{l}0.0698 \\
{[0.24]}\end{array}$ & \\
\hline Observations & 11305 & 11298 & 11303 & 11279 & 11269 & 11304 & 11305 & 11305 & 11305 & 11304 & 11304 & \\
\hline Type of behavior & neither & black & black & neither & black & neither & neither & white & white & neither & white & \\
\hline
\end{tabular}

Note: All models include the full set of control variables depicted in table 4.

Robust standard errors in brackets, ${ }^{* *} p<0.01,{ }^{*} p<0.05,+p<0.1$ 
Table 4b: Classification of behavior by monoracial group, at-home sample (Same rows as Tables 2 and A1)

\begin{tabular}{|c|c|c|c|c|c|c|}
\hline \multirow{2}{*}{$\begin{array}{l}\text { Dependent variable } \\
\text { smoker }\end{array}$} & \multicolumn{2}{|c|}{$\begin{array}{l}\text { Parents' id, intact } \\
\text { family (from Table 4a) }\end{array}$} & \multicolumn{2}{|c|}{$\begin{array}{l}\text { Self-identified } \\
\text { intact families }\end{array}$} & \multicolumn{2}{|c|}{$\begin{array}{l}\text { Self-identified all } \\
\text { respondents }\end{array}$} \\
\hline & & White & & White & & White \\
\hline smoke_30 & & White & & White & & White \\
\hline smoke_reg & & White & & White & & White \\
\hline pot & & White & & White & & White \\
\hline odrugs & & White & & White & & White \\
\hline drank12 & & White & & White & & White \\
\hline drunken & & White & & White & & White \\
\hline drank_weekly & & White & & White & & White \\
\hline hadsex & Black & & Black & & Black & \\
\hline $\begin{array}{l}\text { suspend } \\
\text { expelled }\end{array}$ & Black & & Black & & $\begin{array}{l}\text { Black } \\
\text { Black }\end{array}$ & \\
\hline school_skip & & White & & White & & White \\
\hline feelclose & & White & & White & & White \\
\hline partschoold & & & & & Black & \\
\hline prejudicedd & & White & & White & & White \\
\hline safeatschool & & & & & Black & \\
\hline happyschoold & & White & & White & & White \\
\hline teachfaird & & White & & White & & White \\
\hline school_index & & & & & & White \\
\hline tchr_trouble & & & & & & \\
\hline pay_attnd & & White & & White & & White \\
\hline homeworkd & & White & & White & & White \\
\hline getalongd & & & & & & White \\
\hline schtrouble_index & & White & & White & & White \\
\hline graffiti & & White & & White & & White \\
\hline property & & White & & White & & White \\
\hline lie & & & & & & \\
\hline $\begin{array}{l}\text { steal } \\
\text { drive wo }\end{array}$ & & & & & & \\
\hline enter_steal & & & & & & White \\
\hline steal_over50 & & White & & White & & White \\
\hline steal_less50 & & White & & White & & White \\
\hline bad_public & & & & & & White \\
\hline delinq_index & & & & & & White \\
\hline housework & & & & & & \\
\hline video & Black & & Black & & Black & \\
\hline computer_games & Black & & Black & & Black & \\
\hline watchtv & Black & & Black & & Black & \\
\hline hobbies & & & & White & & White \\
\hline tv video & & & & & Black & \\
\hline skating & & White & & White & & White \\
\hline sports & & White & & White & & \\
\hline exercise & & & & & Black & \\
\hline hangfriends & & White & & & & White \\
\hline
\end{tabular}

Note: Empty cells indicate that the coefficient on the black indicator variabe was not significant. 
Table 4c: Classification of behavior by monoracial group, in-school sample (Same rows as Table A2)

\section{Dependent variable}

Smoked cigarettes at least once in past year

Smoked cigarettes at least weekly during past year

Smoked cigarettes at least once a month last year

Smoke cigarettes nearly every day

Drank alcohol at least once in past year

Drank alcohol at least weekly during past year

Drank alcohol at least once a month in past year

Been drunk at least once during past year

Been drunk at least weekly during past year

Was drunk at least once per month last year

Index of self-esteem, lower scores indicate better self-esteem

Try very hard to do school work

Index of attitude towards school, higher scores=better attitude

Been in a fight last year

Index of risky behaviors-higher scores=more risky behavior

Watch very little TV during school week

Member of academic club

Member of the band or the dance team

Involved in school sports

Member of school newspaper or yearbook

Member of student council

Member of the honor society

Selfhealth rating 1-5 with higher scores being poorer health Index of missed activities due to health, higher \#s indicates more Index of health troubles--higher numbers indicate more trouble cigs

cigs_week

cigs_month

smoker

alcohol

alcohol_week

alcohol_month

drunk

drunk_week

drunk month

selfesteem

schoolwk

school_index

fight

risky_index

tvschool

academic_club

band_dance

sports

news_year

studentcouncil

honorsociety

selfhealth

missactivity

healthtrouble
Self-identified Self-identified

intact families all respondents

White White

White White

White White

White White

White White

White White

White White

White White

White White

White White

White

White

Black Black

Black

Black

Black

Black

White White

White White

White White

Black Black

Black Black

White

Black

White

White

Black

White

White

White 
Table 6: Indices of black/white behaviors, summary statistics for each racial group

At-home sample, Parent-identified race, Intact families

\begin{tabular}{|c|c|c|c|c|c|}
\hline & \multicolumn{5}{|c|}{ Mixed } \\
\hline & $\mathrm{N}$ & Mean & SD & Min & Max \\
\hline White Dichotomous & 106 & 8.36 & 2.77 & 2 & 16 \\
\hline White Frequency & 99 & 0.46 & 0.30 & 0 & 1.6 \\
\hline White All & 99 & 8.96 & 2.87 & 2.38 & 17.6 \\
\hline Balck Dichotomous & 100 & 0.59 & 0.68 & 0 & 2 \\
\hline Black Frequency & 106 & 0.22 & 0.18 & 0.01 & 1.04 \\
\hline Black All & 100 & 0.81 & 0.72 & 0.01 & 2.75 \\
\hline Agg. Dichotomous & 106 & 9.70 & 2.73 & 3 & 17 \\
\hline Agg. Frequency & 99 & 3.24 & 0.35 & 2.23 & 4.28 \\
\hline Agg. All & 99 & 13.17 & 2.70 & 7.25 & 20.79 \\
\hline
\end{tabular}

$$
\begin{aligned}
& \underline{\text { Black }} \\
& \mathrm{N} \\
& \begin{array}{rrrrr}
\multicolumn{1}{c}{\text { Mean }} & \text { SD } & \multicolumn{2}{c}{\text { Min }} & \multicolumn{2}{c}{\text { Max }} \\
1543 & 7.14 & 2.23 & 2 & 16 \\
1547 & 0.40 & 0.26 & 0 & 1.15 \\
1506 & 7.58 & 2.34 & 2 & 16.88 \\
1544 & 0.68 & 0.70 & 0 & 2 \\
1577 & 0.22 & 0.21 & 0 & 1.55 \\
1534 & 0.90 & 0.74 & 0 & 3.27 \\
1543 & 8.46 & 2.21 & 2 & 17 \\
1537 & 3.18 & 0.31 & 1.73 & 3.99 \\
1497 & 11.70 & 2.27 & 5.98 & 20.11
\end{array}
\end{aligned}
$$

At-home sample, Self-identified race, Intact families

\begin{tabular}{|c|c|c|c|c|c|}
\hline & \multicolumn{5}{|c|}{ Mixed } \\
\hline & $\mathrm{N}$ & Mean & SD & Min & Max \\
\hline White Dichotomous & 331 & 9.79 & 3.12 & 3 & 21 \\
\hline White Frequency & 315 & 1.00 & 0.46 & 0.14 & 2.59 \\
\hline White All & 310 & 10.80 & 3.38 & 3.98 & 23.59 \\
\hline Balck Dichotomous & 322 & 4.25 & 0.98 & 1 & \\
\hline Black Frequency & 337 & 0.20 & 0.23 & 0.01 & 2.17 \\
\hline Black All & 321 & 4.45 & 0.99 & 1.68 & 7.30 \\
\hline Agg. Dichotomous & 331 & 12.54 & 3.13 & 6 & 26 \\
\hline Agg. Frequency & 314 & 3.80 & 0.50 & 1.88 & 5.52 \\
\hline Agg. All & 309 & 16.34 & 3.41 & 7.88 & 31.52 \\
\hline
\end{tabular}

\begin{tabular}{lrrrrr}
\multicolumn{3}{c}{ Mixed } & & & \\
& $N$ & Mean & SD & \multicolumn{2}{c}{ Min Max } \\
White Dichotomous & 61 & 8.44 & 2.81 & 2 & 18 \\
White Frequency & 58 & 0.50 & 0.27 & 0 & 1.03 \\
White All & 57 & 9.00 & 3.02 & 2.38 & 19.03 \\
Balck Dichotomous & 59 & 0.51 & 0.60 & 0 & 2 \\
Black Frequency & 62 & 0.19 & 0.20 & 0.01 & 1.04 \\
Black All & 59 & 0.70 & 0.65 & 0.02 & 2.41 \\
Agg. Dichotomous & 61 & 9.87 & 2.77 & 4 & 19 \\
Agg. Frequency & 58 & 3.32 & 0.33 & 2.23 & 4.02 \\
Agg. All & 57 & 13.32 & 2.92 & 7.25 & 22.96
\end{tabular}

At-home sample, Self-identified race, All respondents

\begin{tabular}{|c|c|c|c|c|c|}
\hline & \multicolumn{5}{|c|}{ Mixed } \\
\hline & $\mathrm{N}$ & Mean & SD & Min & Max \\
\hline White Dichotomous & 365 & 3.22 & 2.57 & 0 & 10 \\
\hline White Frequency & 297 & 1.20 & 0.46 & 0.43 & 3.08 \\
\hline White All & 297 & 4.52 & 2.83 & 0.52 & 13.08 \\
\hline Balck Dichotomous & 347 & 2.44 & 1.02 & 0 & 5 \\
\hline Frequency & 377 & 0.42 & 0.37 & 0 & \\
\hline Black All & 339 & 2.83 & 1.09 & 0.5 & 6 \\
\hline Agg. Dichotomous & 365 & 5.76 & 2.63 & 1 & 13 \\
\hline Agg. Frequency & 292 & 1.79 & 0.48 & 0.60 & 3.82 \\
\hline Agg. All & 292 & 7.69 & 2.74 & 2.05 & 15.46 \\
\hline
\end{tabular}

In-school sample, Self-identified race, Intact families

In-school sample, Self-identified race, All respondents

\begin{tabular}{lrrrrr} 
& \multicolumn{3}{c}{ Mixed } & & \\
& $N$ & Mean & SD & Min & \multicolumn{2}{c}{ Max } \\
White Dichotomous & 733 & 3.63 & 2.80 & 0 & 11 \\
White Frequency & 588 & 1.13 & 0.47 & 0.33 & 3.06 \\
White All & 588 & 4.84 & 3.08 & 0.33 & 13.72 \\
Balck Dichotomous & 701 & 2.40 & 1.05 & 0 & 5 \\
Black Frequency & 757 & 0.47 & 0.38 & 0 & 1 \\
Black All & 682 & 2.84 & 1.11 & 0 & 6 \\
Agg. Dichotomous & 733 & 6.22 & 2.87 & 1 & 13 \\
Agg. Frequency & 577 & 1.69 & 0.51 & 0.36 & 4.05 \\
Agg. All & 577 & 8.00 & 3.08 & 1.90 & 15.53
\end{tabular}

$$
\begin{aligned}
& \text { Black } \\
& \text { N } \\
& \begin{array}{lllll} 
& \multicolumn{1}{c}{\text { Mean }} & \text { SD } & \text { Min } & \multicolumn{1}{c}{\text { Max }} \\
1548 & 7.07 & 2.23 & 1 & 16
\end{array} \\
& \begin{array}{lllll}
1549 & 0.40 & 0.26 & 0 & 1.38
\end{array} \\
& \begin{array}{lllll}
1509 & 7.51 & 2.34 & 1.13 & 16.88
\end{array} \\
& \begin{array}{lllll}
1545 & 0.68 & 0.70 & 0 & 2
\end{array} \\
& \begin{array}{lllll}
1580 & 0.22 & 0.21 & 0 & 1.55
\end{array} \\
& \begin{array}{lllll}
1535 & 0.90 & 0.74 & 0 & 3.27
\end{array} \\
& \begin{array}{llllr}
1548 & 8.38 & 2.23 & 2 & 17
\end{array} \\
& \begin{array}{lllll}
1539 & 3.17 & 0.32 & 1.73 & 4.13
\end{array} \\
& \begin{array}{lllll}
1500 & 11.62 & 2.29 & 4.98 & 20.11
\end{array}
\end{aligned}
$$

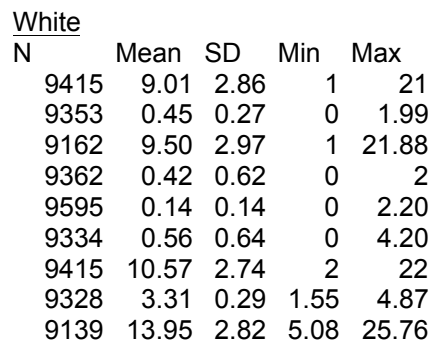

White
\begin{tabular}{rrrrr} 
N \\
Mean SD & \multicolumn{3}{c}{ Min Max } \\
9015 & 8.94 & 2.82 & 0 & 21 \\
8954 & 0.45 & 0.26 & 0 & 1.99 \\
8776 & 9.44 & 2.92 & 0 & 21.88 \\
8960 & 0.42 & 0.62 & 0 & 2 \\
9180 & 0.14 & 0.14 & 0 & 2.20 \\
8933 & 0.56 & 0.64 & 0 & 4.20 \\
9015 & 10.50 & 2.72 & 1 & 22 \\
8930 & 3.31 & 0.29 & 1.55 & 4.87 \\
8754 & 13.89 & 2.78 & 4.08 & 25.76
\end{tabular}

White

N Mean SD Min Max

$\begin{array}{lllll}19392 & 10.38 & 3.26 & 1 & 24\end{array}$

$\begin{array}{lllll}18773 & 0.95 & 0.45 & 0.14 & 3.33\end{array}$

$\begin{array}{lllll}18427 & 11.40 & 3.51 & 1.71 & 25.91\end{array}$

$\begin{array}{lllll}19065 & 4.12 & 0.89 & 0 & 7\end{array}$

$\begin{array}{lllll}19913 & 0.15 & 0.15 & 0 & 2.19\end{array}$

$\begin{array}{lllll}19006 & 4.27 & 0.90 & 0.10 & 8.17\end{array}$

$\begin{array}{lrrrr}19392 & 13.25 & 3.16 & 4 & 27\end{array}$

$\begin{array}{lllll}18721 & 3.81 & 0.46 & 2.10 & 6.30\end{array}$

$\begin{array}{lllll}18377 & 17.13 & 3.42 & 7.77 & 32.27\end{array}$

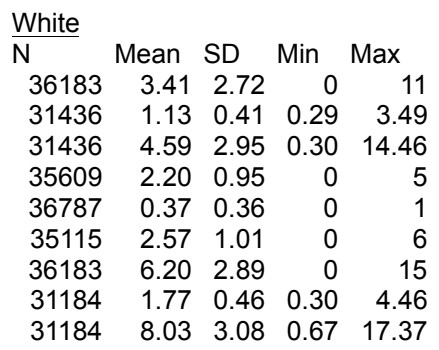

\begin{tabular}{lrlrr} 
Black & \multicolumn{1}{c}{ N } & Mean & SD & Min Max \\
12641 & 2.52 & 2.31 & 0 & 11 \\
9392 & 0.96 & 0.35 & 0.29 & 3.05 \\
9392 & 3.54 & 2.49 & 0.29 & 14.02 \\
11987 & 2.33 & 0.98 & 0 & 5 \\
12755 & 0.46 & 0.38 & 0 & 1 \\
11299 & 2.79 & 1.06 & 0 & 6 \\
12641 & 5.15 & 2.43 & 0 & 14 \\
9089 & 1.52 & 0.49 & 0.31 & 4.05 \\
9089 & 6.77 & 2.60 & 0.43 & 17.85
\end{tabular}

White

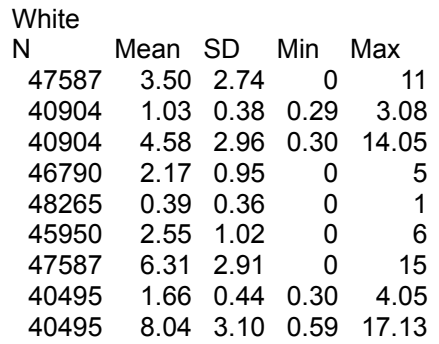


Table 7a: Behavior of mixed-race adolescents; In-home sample, race based on parents (intact family)

\begin{tabular}{|c|c|c|c|c|c|c|c|c|c|}
\hline & $\begin{array}{c}\text { Dichotomous } \\
\text { white }\end{array}$ & $\begin{array}{l}\text { Rescaled } \\
\text { white freq. }\end{array}$ & $\begin{array}{c}\text { All white } \\
\text { behaviors }\end{array}$ & $\begin{array}{c}\text { Dichotomous } \\
\text { Black }\end{array}$ & $\begin{array}{l}\text { Rescaled } \\
\text { black freq. }\end{array}$ & $\begin{array}{c}\text { All black } \\
\text { behaviors }\end{array}$ & $\begin{array}{c}\text { Dichot. white }+ \\
\text { rev'd black }\end{array}$ & $\begin{array}{c}\text { Freq. White + } \\
\text { rev'd black }\end{array}$ & $\begin{array}{l}\text { All white + } \\
\text { rev'd black }\end{array}$ \\
\hline black & $\begin{array}{l}-1.444^{\star *} \\
{[0.089]}\end{array}$ & $\begin{array}{l}-0.0327^{* *} \\
{[0.0096]}\end{array}$ & $\begin{array}{l}-1.488^{* *} \\
{[0.094]}\end{array}$ & $\begin{array}{l}0.173^{* *} \\
{[0.023]}\end{array}$ & $\begin{array}{l}0.0654^{* *} \\
{[0.00671}\end{array}$ & $\begin{array}{l}0.239^{* *} \\
{[0.024]}\end{array}$ & $\begin{array}{l}-1.596^{* *} \\
{[0.087]}\end{array}$ & $-0.0977^{* *}$ & $\begin{array}{l}-1.724^{* *} \\
{[0.0911}\end{array}$ \\
\hline mixed & $-0.529^{*}$ & 0.00990 & -0.447 & $0.119+$ & $0.0679^{\star \star}$ & $0.191^{* *}$ & $-0.686^{\star *}$ & $-0.0606+$ & $-0.635^{*}$ \\
\hline & {$[0.26]$} & {$[0.029]$} & {$[0.28]$} & {$[0.062]$} & {$[0.018]$} & {$[0.067]$} & {$[0.26]$} & {$[0.035]$} & {$[0.27]$} \\
\hline Constant & $-12.08^{\star *}$ & $-0.816^{\star \star}$ & $-9.066^{\star *}$ & $-1.881^{* *}$ & $0.371^{* *}$ & $-1.509^{* \star}$ & $-9.744^{* *}$ & $1.855^{\star \star}$ & -2.649 \\
\hline & [2.05] & {$[0.23]$} & {$[2.19]$} & {$[0.45]$} & {$[0.14]$} & {$[0.48]$} & {$[2.00]$} & {$[0.26]$} & [2.10] \\
\hline Observations & 11050 & 10985 & 10753 & 10992 & 11264 & 10954 & 11050 & 10950 & 10721 \\
\hline R-sq & 0.106 & 0.0348 & 0.107 & 0.154 & 0.0754 & 0.157 & 0.117 & 0.0422 & 0.121 \\
\hline p-val black = zero & 0 & 0.000704 & 0 & 0 & 0 & 0 & 0 & 0 & 0 \\
\hline Type of behavior & white & white & white & black & black & black & white & white & white \\
\hline p-val mixed = zero & 0.0436 & 0.737 & 0.110 & 0.0559 & 0.000199 & 0.00423 & 0.00826 & 0.0834 & 0.0176 \\
\hline p-val mixed = black & 0.000657 & 0.159 & 0.000288 & 0.405 & 0.896 & 0.488 & 0.000616 & 0.301 & 0.0000726 \\
\hline p-val joint hypotheses & 0 & 0.00266 & 0 & 0 & 0 & 0 & 0 & 0 & 0 \\
\hline Identity & unique combo & neither & white & black & black & black & unique combo & black & unique combo \\
\hline sd biraical subpopulation & 2.659 & 0.251 & 2.738 & 0.529 & 0.135 & 0.547 & 2.601 & 0.279 & 2.632 \\
\hline sd white subpopluation & 2.710 & 0.256 & 2.805 & 0.565 & 0.131 & 0.581 & 2.600 & 0.279 & 2.666 \\
\hline sd black subpopulation & 2.147 & 0.252 & 2.243 & 0.631 & 0.200 & 0.671 & 2.132 & 0.305 & 2.190 \\
\hline sd monoracial subpopulation & 2.621 & 0.258 & 2.728 & 0.606 & 0.149 & 0.628 & 2.492 & 0.287 & 2.583 \\
\hline Differences in stdev & $\begin{array}{l}\operatorname{mix}>b \\
\operatorname{mix}>\text { mono }\end{array}$ & $\operatorname{mix}<\operatorname{mono}$ & $\operatorname{mix}>b$ & $\operatorname{mix}<\operatorname{mono}$ & $\begin{array}{l}\operatorname{mix}>\mathrm{w} \\
\operatorname{mix}<\operatorname{mono}\end{array}$ & $\begin{array}{l}\operatorname{mix}<\mathrm{w} \\
\operatorname{mix}<\operatorname{mono}\end{array}$ & $\begin{array}{l}\operatorname{mix}>b \\
\operatorname{mix}>\text { mono }\end{array}$ & $\operatorname{mix}<w$ & $\begin{array}{l}\operatorname{mix}>b \\
\operatorname{mix}>\text { mono }\end{array}$ \\
\hline
\end{tabular}

Note: all models include the full set of control variables depicted in Table 3

The row "Type of behavior" summarizes the p-value above it and its associated coefficient.

The row "Identity" summarizes the p-values above it and their associated coefficients

The row "Differences in stdev" summarizes the standard deviations reported above only for significant differences ( $p$-values not reported here).

"mix" = biracial subpopulation, "b" = black subpopulation, "w" = white subpopulation, "mono" = the black and the white subpopulations

Robust standard errors in brackets, ${ }^{* *} p<0.01,{ }^{*} p<0.05,+p<0.1$ 
Table 7b: Identity of mixed-race adolescents, all samples

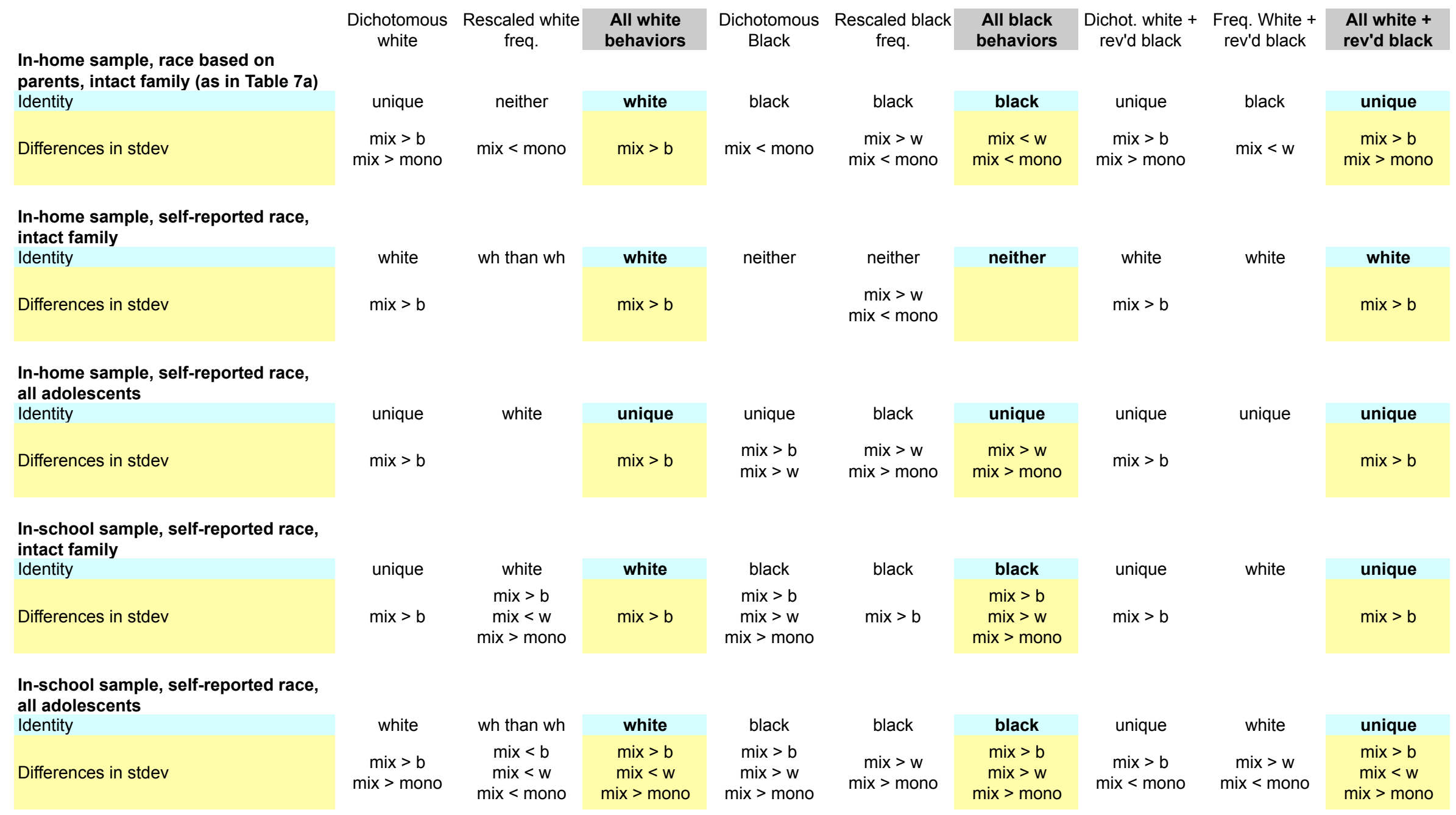


Table A1: Dependent variables, additional at-home sample (waves 1 and 2) (Same rows as Table 2)

\begin{tabular}{|c|c|c|c|c|c|c|c|c|c|c|c|c|}
\hline \multirow{3}{*}{ Variable } & \multicolumn{6}{|c|}{ Self-identified, intact families } & \multicolumn{6}{|c|}{ Self-identified, all families } \\
\hline & \multicolumn{2}{|c|}{ Black \& White } & \multicolumn{2}{|c|}{ Black } & \multicolumn{2}{|c|}{ White } & \multicolumn{2}{|c|}{ Black \& White } & \multicolumn{2}{|c|}{ Black } & \multicolumn{2}{|c|}{ White } \\
\hline & Obs & $\begin{array}{l}\text { Mean } \\
\text { (Std) }\end{array}$ & Obs & $\begin{array}{c}\text { Mean } \\
\text { (Std) }\end{array}$ & Obs & $\begin{array}{c}\text { Mean } \\
\text { (Std) }\end{array}$ & Obs & $\begin{array}{c}\text { Mean } \\
\text { (Std) }\end{array}$ & Obs & $\begin{array}{c}\text { Mean } \\
\text { (Std) }\end{array}$ & Obs & $\begin{array}{c}\text { Mean } \\
\text { (Std) }\end{array}$ \\
\hline smoker & 62 & 0.1452 & 1590 & 0.056 & 9206 & 0.1981 & 338 & 0.183 & 6875 & 0.073 & 19973 & 0.255 \\
\hline smoke_30 & 62 & 0.258 & 1583 & 0.119 & 9162 & 0.297 & 336 & 0.244 & 6829 & 0.142 & 19874 & 0.346 \\
\hline smoker_reg & 62 & 0.065 & 1591 & 0.019 & 9209 & 0.157 & 338 & 0.104 & 6883 & 0.035 & 19983 & 0.202 \\
\hline pot & 61 & 0.213 & 1563 & 0.111 & 9098 & 0.160 & 335 & 0.254 & 6720 & 0.158 & 19662 & 0.197 \\
\hline odrugs & 62 & 0.016 & 1573 & 0.007 & 9146 & 0.037 & 337 & 0.018 & 6789 & 0.007 & 19802 & 0.047 \\
\hline drank12 & 62 & 0.435 & 1587 & 0.285 & 9202 & 0.469 & 338 & 0.447 & 6858 & 0.330 & 19950 & 0.509 \\
\hline drunken & 62 & 0.210 & 1588 & 0.106 & 9199 & 0.289 & 337 & 0.267 & 6863 & 0.137 & 19946 & 0.328 \\
\hline drank_weekly & 62 & 0.048 & 1591 & 0.104 & 9209 & 0.131 & 338 & 0.127 & 6883 & 0.128 & 19983 & 0.142 \\
\hline hadsex & 62 & 0.387 & 1575 & 0.451 & 9135 & 0.298 & 338 & 0.485 & 6798 & 0.548 & 19822 & 0.387 \\
\hline suspend & 59 & 0.153 & 1560 & 0.235 & 9034 & 0.126 & 322 & 0.258 & 6652 & 0.3 & 19230 & 0.181 \\
\hline expelled & 59 & 0.000 & 1559 & 0.037 & 9034 & 0.013 & 322 & 0.019 & 6645 & 0.065 & 19219 & 0.021 \\
\hline school_skip & 62 & $\begin{array}{l}0.452 \\
(1.141)\end{array}$ & 1590 & $\begin{array}{l}0.834 \\
(2.936)\end{array}$ & 9196 & $\begin{array}{l}1.193 \\
(4.851)\end{array}$ & 338 & $\begin{array}{l}1.331 \\
(3.991)\end{array}$ & 6865 & $\begin{array}{l}1.571 \\
(6.086)\end{array}$ & 19946 & $\begin{array}{l}1.896 \\
(6.803)\end{array}$ \\
\hline feelclose & 62 & 0.8226 & 1591 & 0.819 & 9209 & 0.869 & 338 & 0.802 & 6883 & 0.795 & 19983 & 0.831 \\
\hline hool & 62 & 0.806 & 1591 & 0.862 & 9209 & 0.881 & 338 & 0.796 & 6883 & 0.837 & 19983 & 0.836 \\
\hline prejudiced & 62 & 0.581 & 1591 & 0.532 & 9209 & 0.705 & 338 & 0.562 & 6883 & 0.490 & 19983 & 0.697 \\
\hline safe at school & 62 & 0.758 & 1591 & 0.827 & 9209 & 0.888 & 338 & 0.778 & 6883 & 0.799 & 19983 & 0.847 \\
\hline happyschool & 62 & 0.742 & 1591 & 0.806 & 9209 & 0.852 & 338 & 0.743 & 6883 & 0.781 & 19983 & 0.812 \\
\hline teach & 62 & 0.677 & 1591 & 0.762 & 9209 & 0.803 & 338 & 0.689 & 6883 & 0.732 & 19983 & 0.767 \\
\hline school_index & 58 & $\begin{array}{l}1.000 \\
(0.494)\end{array}$ & 1548 & $\begin{array}{l}0.895 \\
(0.462)\end{array}$ & 8940 & $\begin{array}{l}0.878 \\
(0.442)\end{array}$ & 317 & $\begin{array}{l}0.986 \\
(0.497)\end{array}$ & 6558 & $\begin{array}{l}0.911 \\
(0.476)\end{array}$ & 18972 & $\begin{array}{l}0.928 \\
(0.464)\end{array}$ \\
\hline tchr_trouble & 62 & 0.6774 & 1591 & 0.5594 & 9209 & 0.5818 & 338 & 0.633 & 6883 & 0.621 & 19983 & 0.601 \\
\hline pay_attnd & 62 & 0.839 & 1591 & 0.666 & 9209 & 0.789 & 338 & 0.775 & 6883 & 0.680 & 19983 & 0.792 \\
\hline homeworkd & 62 & 0.806 & 1591 & 0.629 & 9209 & 0.721 & 338 & 0.737 & 6883 & 0.656 & 19983 & 0.738 \\
\hline getalongd & 62 & 0.677 & 1591 & 0.570 & 9209 & 0.600 & 338 & 0.609 & 6883 & $0.5 \varepsilon$ & 19983 & 0.619 \\
\hline schtrouble_index & 58 & $\begin{array}{l}0.996 \\
(0.531)\end{array}$ & 1550 & $\begin{array}{l}0.777 \\
(0.512)\end{array}$ & 8965 & $\begin{array}{l}0.878 \\
(0.507)\end{array}$ & 317 & $\begin{array}{l}0.923 \\
(0.522)\end{array}$ & 6580 & $\begin{array}{l}0.823 \\
(0.521)\end{array}$ & 19016 & $\begin{array}{l}0.904 \\
(0.515)\end{array}$ \\
\hline graffiti & 62 & 0.1452 & 1580 & 0.0475 & 9169 & 0.0739 & 336 & 0.110 & 6818 & 0.060 & 19864 & 0.081 \\
\hline property & 62 & 0.242 & 1580 & 0.109 & 9171 & 0.173 & 337 & 0.220 & 6816 & 0.1 & 19864 & 0.172 \\
\hline lie & 62 & 0.532 & 1578 & 0.501 & 9171 & 0.501 & 336 & 0.521 & 6809 & 0.487 & 19852 & 0.502 \\
\hline steal & 62 & 0.323 & 1576 & 0.186 & 9168 & 0.195 & 337 & 0.294 & 6816 & 0.198 & 19851 & 0.217 \\
\hline drive_wo & 62 & 0.048 & 1581 & 0.085 & 9173 & 0.075 & 337 & 0.080 & 6828 & 0.097 & 19876 & 0.088 \\
\hline steal & 62 & 0.06 & 1589 & 0.0 & 9202 & 0.037 & 337 & 0.062 & 6867 & & 19952 & 0.047 \\
\hline over50 & 62 & 0.032 & 1581 & 0.0 & 9175 & 0.036 & 337 & 0.056 & 6826 & & 19876 & 0.050 \\
\hline _less50 & 62 & 0.274 & 1581 & 0.130 & 9171 & 0.171 & 337 & 0.220 & 6828 & 0.140 & 19859 & 0.187 \\
\hline bad_public & 62 & 0.548 & 1579 & 0.412 & 9171 & 0.455 & 337 & 0.507 & 6826 & 0.408 & 19862 & 0.457 \\
\hline delinq_index & 62 & $\begin{array}{l}0.355 \\
(0.415)\end{array}$ & 1566 & $\begin{array}{l}0.216 \\
(0.291)\end{array}$ & 9141 & $\begin{array}{l}0.243 \\
(0.325)\end{array}$ & 335 & $\begin{array}{l}0.322 \\
(0.383)\end{array}$ & 6758 & $\begin{array}{l}0.238 \\
(0.321)\end{array}$ & 19775 & $\begin{array}{l}0.263 \\
(0.350)\end{array}$ \\
\hline housework & 62 & 1 & 1591 & & 9209 & & 338 & & 6879 & & & \\
\hline video & 62 & $\begin{array}{l}6.339 \\
(12.89)\end{array}$ & 1588 & $\begin{array}{l}5.856 \\
(9.01)\end{array}$ & 9206 & $\begin{array}{l}3.686 \\
(5.64)\end{array}$ & 338 & $\begin{array}{l}5.731 \\
(10.66)\end{array}$ & 6866 & $\begin{array}{l}6.309 \\
(10.16)\end{array}$ & 19964 & $\begin{array}{l}3.837 \\
(6.15)\end{array}$ \\
\hline computer_games & 62 & $\begin{array}{l}2.4194 \\
(7.185)\end{array}$ & 1589 & $\begin{array}{l}3.5525 \\
(7.79)\end{array}$ & 9209 & $\begin{array}{l}2.3253 \\
(5.504)\end{array}$ & 338 & $\begin{array}{l}3.142 \\
(8.32)\end{array}$ & 6875 & $\begin{array}{l}3.490 \\
(7.80)\end{array}$ & 19973 & $\begin{array}{l}2.399 \\
(5.88)\end{array}$ \\
\hline radio & 62 & $\begin{array}{l}12.516 \\
(15.68)\end{array}$ & 1589 & $\begin{array}{l}16.125 \\
(19.94)\end{array}$ & 9185 & $\begin{array}{l}15.413 \\
(18.46)\end{array}$ & 338 & $\begin{array}{l}15.325 \\
(19.02)\end{array}$ & 6862 & $\begin{array}{l}17.503 \\
(26.79)\end{array}$ & 19926 & $\begin{array}{l}17.364 \\
(23.48)\end{array}$ \\
\hline watchtv & 62 & $\begin{array}{l}16.935 \\
(17.73)\end{array}$ & 1581 & $\begin{array}{l}20.8 \\
(18.91)\end{array}$ & 9183 & $\begin{array}{l}13.134 \\
(12.31)\end{array}$ & 337 & $\begin{array}{l}17.199 \\
(16.11)\end{array}$ & 6833 & $\begin{array}{l}20.339 \\
(18.41)\end{array}$ & 19921 & $\begin{array}{l}13.839 \\
(13.26)\end{array}$ \\
\hline & 62 & 0.8226 & 1591 & 0.7932 & 9208 & 0.8438 & 338 & 0.790 & 6881 & 0.764 & 19981 & 0.807 \\
\hline tv_video & 62 & 1.000 & 1591 & 0.981 & 9209 & 0.969 & 338 & 0.979 & 6881 & 0.972 & 19982 & 0.962 \\
\hline skating & 62 & 0.339 & 1591 & 0.299 & 9209 & 0.427 & 338 & 0.352 & 6881 & 0.304 & 19982 & 0.398 \\
\hline sports & 62 & 0.726 & 1591 & 0.662 & 9209 & 0.756 & 338 & 0.719 & 6881 & 0.672 & 19982 & 0.718 \\
\hline exceercise & 62 & 0.806 & 1591 & 0.847 & 9208 & 0.837 & 338 & 0.876 & 6881 & 0.850 & 19981 & 0.828 \\
\hline hangfriends & 62 & 0.968 & 1591 & 0.901 & 9208 & 0.933 & 338 & 0.908 & 6881 & 0.895 & 19981 & 0.925 \\
\hline
\end{tabular}


Table A2: Dependent variables, in-school samples (Similar to Table 2)

Smoked cigarettes at least once in past year Smoked cigarettes at least weekly during past yea Smoked cigarettes at least once a month last year Smoke cigarettes nearly every day

Drank alcohol at least once in past year

Drank alcohol at least weekly during past year

Drank alcohol at least once a month in past year

Been drunk at least once during past year

Been drunk at least weekly during past year

Was drunk at least once per month last year

Index of self-esteem, lower scores indicate better self-esteem

Try very hard to do school work

Index of attitude towards school, higher scores=better attitude

Been in a fight last year

Index of risky behaviors-higher scores=more risky behavior

Watch very little TV during school week

Member of academic club

Member of the band or the dance team

Involved in school sports

Member of school newspaper or yearbook

Member of student council

Member of the honor society

Selfhealth rating 1-5 with higher scores being poorer health

Index of missed activities due to health, higher \#s indicates more

Index of health troubles--higher numbers indicate more trouble

Black/white $\begin{gathered}\text { Intact Families } \\ \text { Black }\end{gathered}$
$\begin{gathered}\text { Obs Mean } \\ \text { (Std) }\end{gathered}$

cigs

cigs_week

cigs_month

smoker

alcohol

alcohol_week

alcohol_month

drunk

drunk week

drunk_month

selfesteem

schoolwk

school_index

fight

risky_index

tvschool

academic club

band_dance

sports

news_year

honorsociety

selfhealth

missactivity

healthtrouble $\begin{array}{lllll}370 & 0.132 & 6051 & 0.056 & 36618 \\ 370 & 0.168 & 6051 & 0.175 & 36618 \\ 370 & 0.078 & 6051 & 0.025 & 36618\end{array}$

$\begin{array}{lllll}370 & 0.078 & 6051 & 0.025 & 36618\end{array}$

$\begin{array}{lllll}371 & 0.580 & 6030 & 0.468 & 36550\end{array}$

$\begin{array}{llllll}371 & 0.119 & 6030 & 0.071 & 36550\end{array}$

$\begin{array}{lllll}371 & 0.461 & 6030 & 0.397 & 36550\end{array}$

$\begin{array}{lllll}366 & 0.295 & 5970 & 0.199 & 36392\end{array}$

$\begin{array}{lllll}366 & 0.077 & 5970 & 0.038 & 36392\end{array}$

$322 \begin{array}{rrrr}1.979 & 4976 & 1.897 & 33394 \\ (0.624) & & (.573) & \end{array}$

(0.601)

$\begin{array}{llllll}398 & 0.837 & 6628 & 0.876 & 37812 & 0.866\end{array}$

$\begin{array}{llllll}377 & 0.420 & 6026 & 0.439 & 36787 & 0.371\end{array}$ (.3324)

$(.4305)$

(0.5544)

$\begin{array}{llllll}347 & 0.519 & 5607 & 0.470 & 35609 & 0.409\end{array}$ $\begin{array}{lrrrrr}355 & 1.254 & 5766 & 0.889 & 35605 & 1.225 \\ & (1.234) & & (.826) & & (1.057)\end{array}$

$\begin{array}{llllll}398 & 0.166 & 6628 & 0.112 & 37812 & 0.262 \\ 398 & 0.312 & 6628 & 0.229 & 37812 & 0.257\end{array}$

$\begin{array}{llllll}398 & 0.312 & 6628 & 0.229 & 37812 & 0.257\end{array}$

$\begin{array}{lllllll}398 & 0.359 & 6628 & 0.310 & 37812 & 0.283\end{array}$

$\begin{array}{lllllll}398 & 0.563 & 6628 & 0.517 & 37812 & 0.533\end{array}$

$\begin{array}{llllll}398 & 0.143 & 6628 & 0.107 & 37812\end{array}$

$\begin{array}{llllll}398 & 0.095 & 6628 & 0.091 & 37812 & 0.078 \\ 398 & 0.138 & 6628 & 0.086 & 37812 & 0.110\end{array}$

$\begin{array}{llllll}379 & 2.082 & 6197 & 1.999 & 37005 & 2.044\end{array}$ $(1.001)$

(.950)

2.044
$(0.891)$
0.279

$\begin{array}{llllll}351 & 0.378 & 5636 & 0.287 & 35635 & 0.279\end{array}$

$\begin{array}{llllll}339 & 1.352 & 5542 & (.409) & & (0.407) \\ & 1.093 & 35108 & 1.217\end{array}$

$$
\text { (0.765) }
$$

(.7669)

$(0.635)$ $\begin{array}{lllll}366 & 0.219 & 5970 & 0.161 & 36392\end{array}$

Black/white $\begin{gathered}\text { All Families } \\ \text { Black }\end{gathered}$
$\begin{gathered}\text { Obs Mean } \\ \text { (Std) }\end{gathered} \quad \begin{aligned} & \text { Mean } \\ & \text { (Std) }\end{aligned}$ Obs $\begin{gathered}\text { Mean } \\ \text { (Std) }\end{gathered}$

$\begin{array}{llllll}742 & 0.373 & 12930 & 0.251 & 48214 & 0.404\end{array}$

$\begin{array}{llllll}742 & 0.198 & 12930 & 0.069 & 48214 & 0.211\end{array}$

$\begin{array}{llllll}742 & 0.175 & 12930 & 0.181 & 48214 & 0.193\end{array}$

$\begin{array}{llllll}742 & 0.143 & 12930 & 0.036 & 48214 & 0.136 \\ 746 & 0.629 & 12897 & 0.501 & 48102 & 0.576\end{array}$

$\begin{array}{lllllll}746 & 0.168 & 12897 & 0.090 & 48102 & 0.120\end{array}$

$\begin{array}{lllllll}746 & 0.461 & 12897 & 0.411 & 48102 & 0.456\end{array}$

$\begin{array}{llllll}746 & 0.461 & 12897 & 0.411 & 48102 & 0.456\end{array}$

$\begin{array}{llllll}736 & 0.372 & 12768 & 0.230 & 47901 & 0.349 \\ 736 & 0.120 & 12768 & 0.054 & 47901 & 0.071\end{array}$

$\begin{array}{llllll}736 & 0.120 & 12768 & 0.054 & 47901 & 0.071 \\ 736 & 0.253 & 12768 & 0.176 & 47901 & 0.279\end{array}$

$\begin{array}{llllll}639 & 2.075 & 10420 & 1.941 & 43625 & 1.946\end{array}$

(0.687) (.596)

$(.613)$

$\begin{array}{llllll}815 & 0.774 & 14640 & 0.842 & 50104 & 0.851\end{array}$

$\begin{array}{llllll}757 & 0.468 & 12755 & 0.464 & 48265 & 0.386\end{array}$

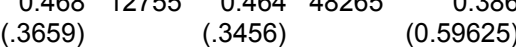

$\begin{array}{llllll}701 & 0.555 & 11987 & 0.498 & 46790 & 0.429\end{array}$

$\begin{array}{llllll}711 & 1.491 & 12224 & 0.950 & 46782 & 1.276\end{array}$

$\begin{array}{ll}(1.435) & (.915)\end{array}$

(1.090)

$\begin{array}{llllll}815 & 0.156 & 14640 & 0.111 & 50104 & 0.256\end{array}$

$\begin{array}{llllll}815 & 0.281 & 14640 & 0.217 & 50104 & 0.245\end{array}$

$\begin{array}{llllll}815 & 0.339 & 14640 & 0.285 & 50104 & 0.270\end{array}$

$\begin{array}{llllll}815 & 0.525 & 14640 & 0.495 & 50104 & 0.514\end{array}$

$\begin{array}{llllll}815 & 0.148 & 14640 & 0.103 & 50104 & 0.099\end{array}$

$\begin{array}{llllll}815 & 0.107 & 14640 & 0.082 & 50104 & 0.073\end{array}$

$\begin{array}{llllll}815 & 0.126 & 14640 & 0.071 & 50104\end{array}$

0.099

$\begin{array}{llllll}763 & 2.223 & 13340 & 2.057 & 48754 & 2.085\end{array}$

$\begin{array}{lll}(1.072) & (.982) & (0.914)\end{array}$

$\begin{array}{llllll}713 & 0.472 & 11908 & 0.321 & 46798 & 0.297\end{array}$

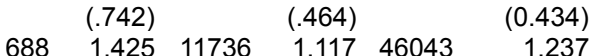

$\begin{array}{lll}(.799) & (0.677) & (0.652)\end{array}$ 
Table A3: Control variables, additional at-home samples (waves $1 \& 2$ )

(Same row labels as Table 3)

\begin{tabular}{|c|c|c|c|c|c|c|c|c|c|c|c|}
\hline \multicolumn{6}{|c|}{ Self-id, intact families } & \multicolumn{6}{|c|}{ Self-id, all respondents } \\
\hline \multicolumn{2}{|c|}{ Black/white } & \multicolumn{2}{|c|}{ Black } & \multicolumn{2}{|c|}{ White } & \multicolumn{2}{|c|}{ Black white } & \multicolumn{2}{|c|}{ Black } & \multicolumn{2}{|c|}{ White } \\
\hline Obs & $\begin{array}{l}\text { Mean } \\
\text { (Std) }\end{array}$ & Obs & $\begin{array}{c}\text { Mean } \\
(\text { Std) }\end{array}$ & Obs & $\begin{array}{l}\text { Mean } \\
\text { (Std) }\end{array}$ & Obs & $\begin{array}{l}\text { Mean } \\
(\text { Std) }\end{array}$ & Obs & $\begin{array}{c}\text { Mean } \\
\text { (Std) }\end{array}$ & Obs & $\begin{array}{c}\text { Mean } \\
\text { (Std) }\end{array}$ \\
\hline 62 & $\begin{array}{r}49.968 \\
(23.914)\end{array}$ & 1591 & $\begin{array}{r}42.190 \\
(35.916)\end{array}$ & 9200 & $\begin{array}{r}52.046 \\
(51.758)\end{array}$ & 338 & $\begin{array}{r}39.657 \\
(61.102)\end{array}$ & 6882 & $\begin{array}{r}24.434 \\
(32.425)\end{array}$ & 19968 & $\begin{array}{r}39.794 \\
(46.868)\end{array}$ \\
\hline 61 & $\begin{array}{r}15.459 \\
(1.766)\end{array}$ & 1590 & $\begin{array}{r}15.642 \\
(1.695)\end{array}$ & 9208 & $\begin{array}{r}15.667 \\
(1.669)\end{array}$ & 337 & $\begin{array}{r}15.653 \\
(1.755)\end{array}$ & 6881 & $\begin{array}{r}15.839 \\
(1.738)\end{array}$ & 19981 & $\begin{array}{l}15.842 \\
(1.701)\end{array}$ \\
\hline 62 & 0.581 & 1591 & 0.541 & 9209 & 0.501 & 338 & 0.556 & 6883 & 0.533 & 19983 & 0.508 \\
\hline 62 & 0.484 & 1591 & 0.426 & 9209 & 0.241 & 338 & 0.497 & 6883 & 0.511 & 19983 & 0.281 \\
\hline 62 & 0.145 & 1591 & 0.272 & 9209 & 0.319 & 338 & 0.145 & 6883 & 0.199 & 19983 & 0.300 \\
\hline 62 & 0.435 & 1591 & 0.397 & 9209 & 0.376 & 338 & 0.444 & 6883 & 0.372 & 19983 & 0.371 \\
\hline 62 & 0.113 & 1591 & 0.045 & 9209 & 0.285 & 338 & 0.178 & 6883 & 0.047 & 19983 & 0.270 \\
\hline 62 & 0.113 & 1591 & 0.026 & 9209 & 0.058 & 338 & 0.101 & 6883 & 0.053 & 19983 & 0.076 \\
\hline 62 & $\begin{array}{l}41.758 \\
(4.288)\end{array}$ & 1591 & $\begin{array}{l}42.267 \\
(5.633)\end{array}$ & 9209 & $\begin{array}{l}41.733 \\
(5.021)\end{array}$ & 338 & $\begin{array}{l}41.364 \\
(5.667)\end{array}$ & 6883 & $\begin{array}{l}40.443 \\
(5.562)\end{array}$ & 19983 & $\begin{array}{l}41.112 \\
(5.225)\end{array}$ \\
\hline 62 & $\begin{array}{l}48.226 \\
(8.225)\end{array}$ & 1591 & $\begin{array}{l}45.207 \\
(6.562)\end{array}$ & 9209 & $\begin{array}{l}44.303 \\
(5.925)\end{array}$ & 338 & $\begin{array}{l}45.012 \\
(5.710)\end{array}$ & 6883 & $\begin{array}{l}44.098 \\
(4.933)\end{array}$ & 19983 & $\begin{array}{l}43.875 \\
(5.590)\end{array}$ \\
\hline 62 & 0.935 & 1591 & 0.934 & 9209 & 0.910 & 338 & 0.885 & 6883 & 0.929 & 19983 & 0.887 \\
\hline 62 & 0.968 & 1591 & 0.947 & 9209 & 0.913 & 338 & 0.846 & 6883 & 0.835 & 19983 & 0.860 \\
\hline 62 & 0.242 & 1591 & 0.204 & 9209 & 0.270 & 338 & 0.086 & 6883 & 0.091 & 19983 & 0.185 \\
\hline 62 & 0.677 & 1591 & 0.727 & 9209 & 0.695 & 338 & 0.317 & 6883 & 0.352 & 19983 & 0.550 \\
\hline 62 & 0.081 & 1591 & 0.061 & 9209 & 0.033 & 338 & 0.038 & 6883 & 0.039 & 19983 & 0.034 \\
\hline 62 & 0.355 & 1591 & 0.365 & 9209 & 0.286 & 338 & 0.340 & 6883 & 0.268 & 19983 & 0.239 \\
\hline 62 & 0.581 & 1591 & 0.504 & 9209 & 0.586 & 338 & 0.509 & 6883 & 0.516 & 19983 & 0.559 \\
\hline 62 & 0.065 & 1591 & 0.129 & 9209 & 0.127 & 338 & 0.104 & 6883 & 0.146 & 19983 & 0.135 \\
\hline 62 & 0.081 & 1591 & 0.061 & 9209 & 0.038 & 338 & 0.151 & 6883 & 0.148 & 19983 & 0.080 \\
\hline
\end{tabular}

Income \$

Age

Female

Urban residence

Rural residence

Parent college graduate

Catholic

No religion

Age of mom in years

Age of dad in years

Mom born in US

Dad born in US

Dad's job is management/professional

Dad's job other than mgmt/prof'l

Dad has no job

Mom's job is management/professional

Mom's job other than mgmt/prof'I

Mom has no job

Parent receives welfare
Self-id, intact families 
Table A4: Control variables, in-school samples (Similar to Table 4)
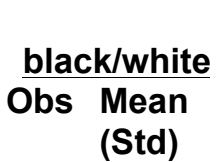

Intact families

(Std)

Obs Mean

(Std)

Obs

white

Mean

\section{Parents on welfare}

\section{Age in years}

\section{Female}

Parent has college education

Mom born in U.S

Dad born in U.S.

Dad is management/professional

Dad job is other than management/prof.

Dad has no job

Adopted

Mom's job is management/professional

Mom's job other than manager/prof.

Mom has no job

Live only with mother

Live only with father

Unknown if living with mom/dad

$\begin{array}{lrlrcr}398 & 0.010 & 6628 & 0.009 & 37812 & 0.003 \\ & (0.100) & & (0.095) & & (0.053) \\ 397 & 14.816 & 6601 & 14.856 & 37780 & 14.976 \\ & (1.705) & & (1.694) & & (1.669) \\ 394 & 0.558 & 6599 & 0.534 & 37655 & 0.501 \\ 398 & 0.698 & 6628 & 0.640 & 37812 & 0.662 \\ 398 & 0.834 & 6628 & 0.905 & 37812 & 0.921 \\ 398 & 0.859 & 6628 & 0.902 & 37812 & 0.921 \\ 398 & 0.236 & 6628 & 0.189 & 37812 & 0.305 \\ 398 & 0.540 & 6628 & 0.559 & 37812 & 0.552 \\ 398 & 0.085 & 6628 & 0.073 & 37812 & 0.043 \\ 398 & 0.000 & 6628 & 0.000 & 37812 & 0.000 \\ 398 & 0.372 & 6628 & 0.321 & 37812 & 0.306 \\ 398 & 0.337 & 6628 & 0.375 & 37812 & 0.387 \\ 398 & 0.181 & 6628 & 0.169 & 37812 & 0.236 \\ 398 & 0.000 & 6628 & 0.000 & 37812 & 0.000 \\ 398 & 0.000 & 6628 & 0.000 & 37812 & 0.000 \\ 398 & 0.000 & 6628 & 0.000 & 37812 & 0.000\end{array}$

\begin{tabular}{|c|c|c|c|c|c|}
\hline \multicolumn{6}{|c|}{ All respondents } \\
\hline \multicolumn{2}{|c|}{ black/white } & \multicolumn{2}{|c|}{ black } & \multicolumn{2}{|c|}{ white } \\
\hline Obs & $\begin{array}{l}\text { Mean } \\
\text { (Std) }\end{array}$ & Obs & $\begin{array}{l}\text { Mean } \\
\text { (Std) }\end{array}$ & Obs & $\begin{array}{l}\text { Mean } \\
\text { (Std) }\end{array}$ \\
\hline 815 & $\begin{array}{r}0.016 \\
(0.125)\end{array}$ & 14640 & $\begin{array}{r}0.016 \\
(0.124)\end{array}$ & 50104 & $\begin{array}{r}0.005 \\
(0.072)\end{array}$ \\
\hline 810 & $\begin{array}{r}14.922 \\
(1.802)\end{array}$ & 14547 & $\begin{array}{r}14.909 \\
(1.727)\end{array}$ & 50046 & $\begin{array}{r}15.000 \\
(1.682)\end{array}$ \\
\hline 801 & 0.564 & 14556 & 0.524 & 49882 & 0.496 \\
\hline 815 & 0.542 & 14640 & 0.4 & 50104 & 0.591 \\
\hline 815 & 0.734 & 14640 & 0.761 & 50104 & 0.846 \\
\hline 815 & 0.492 & 14640 & 0.452 & 50104 & 0.750 \\
\hline 815 & 0.140 & 14640 & 0.094 & 50104 & 0.244 \\
\hline 815 & 0.306 & 14640 & 0.281 & 50104 & 0.451 \\
\hline 815 & 0.055 & 14640 & 0.039 & 50104 & 0.037 \\
\hline 815 & 0.066 & 14640 & 0.029 & 50104 & 0.029 \\
\hline 815 & 0.285 & 14640 & 0.243 & 50104 & 0.277 \\
\hline 815 & & 14640 & 0.3 & 50104 & 0.365 \\
\hline 815 & 0.156 & 14640 & 0.149 & 50104 & 0.207 \\
\hline 815 & 0.317 & 14640 & 0.351 & 50104 & 0.140 \\
\hline 815 & 0.043 & 14640 & 0.032 & 50104 & 0.035 \\
\hline 815 & 0.113 & 14640 & 0.152 & 50104 & 0.050 \\
\hline
\end{tabular}

